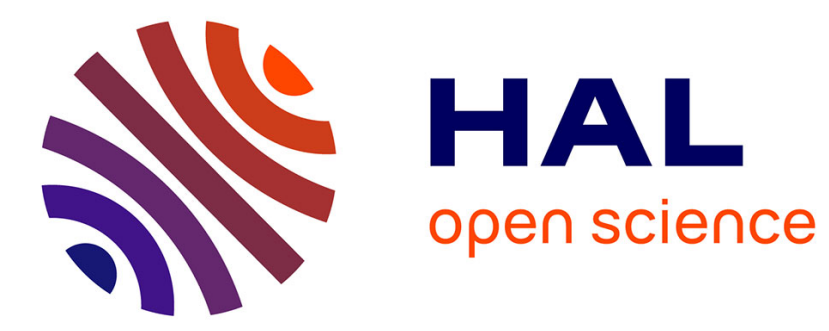

\title{
Cyclic triaxial tests on bituminous mixtures
}

Juliette Blanc, Thomas Gabet, Pierre Hornych, Jean Michel Piau, Hervé Di

Benedetto

\section{To cite this version:}

Juliette Blanc, Thomas Gabet, Pierre Hornych, Jean Michel Piau, Hervé Di Benedetto. Cyclic triaxial tests on bituminous mixtures. Road Materials and Pavement Design, 2015, 16 (1), pp.46-69. 10.1080/14680629.2014.964293 . hal-01470401

\section{HAL Id: hal-01470401 \\ https://hal.science/hal-01470401}

Submitted on 17 Feb 2017

HAL is a multi-disciplinary open access archive for the deposit and dissemination of scientific research documents, whether they are published or not. The documents may come from teaching and research institutions in France or abroad, or from public or private research centers.
L'archive ouverte pluridisciplinaire HAL, est destinée au dépôt et à la diffusion de documents scientifiques de niveau recherche, publiés ou non, émanant des établissements d'enseignement et de recherche français ou étrangers, des laboratoires publics ou privés. 


\title{
Cyclic triaxial tests on bituminous mixtures
}

\author{
Juliette BLANC* - Thomas GABET* — Pierre HORNYCH*- \\ Jean-Michel PIAU*_ Hervé DI BENEDETTO**
}

\author{
*LUNAM Université, IFSTTAR \\ Route de Bouaye CS4 \\ 44341 BOUGUENAIS Cedex FRANCE \\ juliette.blanc@ifsttar.fr \\ thomas.gabet@ifsttar.fr \\ pierre.hornych@ifsttar.fr \\ jean-michel.piau@ifsttar.fr \\ ** University of Lyon/ENTPE - DGCB \& LTDS (UMR CNRS 5513) \\ Rue Maurice Audin \\ 69518 VAULX en VELIN Cedex France \\ herve.di-benedetto@entpe.fr
}

\begin{abstract}
In the framework of a study on rutting of bituminous layers, thermo-controlled triaxial tests under constant confining pressure on homogenous asphalt concrete specimen have been performed. These tests are cyclic sinusoidal tests, with the aim to reproduce in some way the loading and unloading phases due to traffic on roads. The influences of confinement and load frequency have been studied. Tests have highlighted that confinement notably decreases the strain rate as well as the level of strain reached at the end of the test. The tests did not allow to clearly observe the influence of frequency on the response of the material, due to problems of repeatability. In order to avoid such problems, another test procedure was adopted. It consisted in changing either confinement or frequency during the test, with the purpose to see an evolution of strain rate, and to establish correlations. These tests have clearly shown the influence of cyclic loading and the relative influence of loading frequency on the response of asphalt concrete. The main objective of this triaxial program is to develop a numerical model, based on rheological laws, able to predict the behaviour of bituminous layers.
\end{abstract}

KEYWORDS: bituminous mixture - triaxial tests - cyclic sinusoidal tests - rutting - permanent deformation - viscoelastic properties - frequency - confinement 
BLANC, Juliette, GABET, Thomas, HORNYCH, Pierre, PIAU, Jean Michel, DI BENEDETTO, Hervé, 2015, Cyclic triaxial tests on bituminous mixtures , Road materials and pavement design, 1, 16, TAYLOR AND FRANCIS, pp.46-69, DOI: $10.1080 / 14680629.2014 .964293$

\section{Introduction}

Mechanical damage of bituminous pavement layers is due to two main mechanisms: rutting and cracking. This damage is mainly induced by traffic, and especially traffic of heavy and slow vehicles. Our study focuses on rutting, which is characterized by the development of longitudinal ruts due to permanent deformations of pavement layers, which affect safety and comfort of road users. Two types of rutting can be encountered on road structures: large radius rutting generally related to permanent deformation of granular base layers or subgrades, and small radius rutting due to permanent deformations appearing in the bituminous layers, mainly in the wheel path and close to it. Small radius rutting is the subject of this work.

When studying permanent deformations (rutting) appearing in bituminous layers, three main difficulties are encountered. The first problem is the complexity of loading, which is dynamic, local and characterized by a complex geometry and a non-homogeneous distribution pressure. The second difficulty is the complexity of the rheological behaviour of bituminous mixtures, which have a heterogeneous structure, made of a viscous material, the bitumen, and a granular skeleton. From a rheological point of view, bituminous mixtures present characteristics of viscoelastic, viscoplastic, thermosuceptible materials, and their behaviour is also dependent on the triaxial loading path and cyclic loading, like for granular materials. The third difficulty is related to the scales encountered, in terms of cyclic strains (very small), time and number of cycles (very large), which complicate the study of bituminous concrete in the laboratory.

For studying the rutting behaviour of bituminous mixtures in the laboratory, determining representative triaxial stress paths is a key point. Loading paths generated in pavements by moving wheel loads are difficult to reproduce in the laboratory, as shown by (Perraton et al., 2011), and (Gabet et al., 2011). They induce cyclic, three-dimensional loading paths, with stress rotations and evolve with time. Due to the difficulty to simulate accurately such loadings with a typical press, like a thermo-controlled triaxial apparatus, more empirical, simulative tests like the French Wheel tracking test are used for designing bituminous mixes. Although wheel tracking tests apply more realistic loading conditions, they do not allow to determine the rheological properties of the material tested, due to the complex, non homogeneous, stress conditions in the specimen. Thus, triaxial tests, on homogenous specimen are more appropriate for a rheological approach.

The most common method for studying the rheological behaviour of bituminous mixtures consists in using thermo-controlled uniaxial tests (monotonic or cyclic). They allow determining the viscoelastic properties of bituminous mixtures, but in terms of rutting, several authors have emphasized the importance of considering triaxial behaviour with confining pressure (De Visscher et al., 2006, Ebels and Jenkins, 2006, Taherkhani et al., 2007, Taherkhani and Collop, 2006). 
At IFSTTAR, a triaxial apparatus has been developed for studying bituminous mixes (Sohm et al., 2010). It is able to perform a large range of tests: monotonic creep tests, complex modulus tests and cyclic permanent deformation tests at small and large strain levels (from $50 \mu$ strain up to $5 \%$ ) and at different temperatures (from 5 to $60^{\circ} \mathrm{C}$ ), different frequencies (up to $10 \mathrm{~Hz}$ ) and different levels of confining pressure. First tests performed with this apparatus have been presented by Sohm et al. (2012). This first study focused on the monotonic creep behaviour of bituminous mixtures, in order to examine the effect of different levels of vertical stress, confining pressure and temperature. These tests have shown, in particular, that the level of confinement has a very significant effect on the response of asphalt concretes. When confinement increases, the strain rate decreases and the volumetric behaviour of bituminous mixtures is modified. For a given level of axial strain, volumetric strain is dilatant (volume increase) at low confining pressures and may become contractant for high confining pressures. It has also been shown that increasing temperature during the creep test leads to higher strain rates, as it is the case in the viscoelastic domain.

Another interesting result of Sohm et al (2012) was that the time temperature superposition principle (TTSP), usually considered as valid in the linear domain for most asphalt concretes, could be extended to the non linear domain even under confinement. This result confirmed previous results presented in the literature, but without confinement (Di Benedetto et al. (2011), Di Benedetto et al. (2008) and Nguyen et al. (2009)), or in the very high frequency domain (Di Benedetto et al., 2010). Finally a viscoelastic-viscoplastic model has been developed in order to simulate the experimental response. It shows both good kinetic and volumetric responses, and in particular reproduces well the dilatant/contractant aspects, despite some limitations for high deviatoric stresses without confinement.

This paper presents results of cyclic sinusoidal triaxial tests, which simulate the stress paths generated in pavements by moving wheel loads. To reproduce such moving loads, cyclic sinusoidal triaxial tests with cyclic confining pressure ((Brown, 1977) and (Brown et al., 1974)) are considered most representative. However, in this work, for technical limitations of the test apparatus, we focus on cyclic triaxial tests with constant confining pressure. Influence of the confining pressure and loading frequency on the evolution of permanent strains and on viscoelastic characteristics of a bituminous mixture are studied.

A first tests program (T1) was performed to evaluate the repeatability of the results and to evaluate the influence of the confining pressure and frequency. In a second test program (T2), the test procedure was modified, to overcome problems of repeatability. With the second procedure, different load sequences, with variable confinement and/or frequency, were applied successively on a single specimen, to avoid the scatter due to the use of several different specimens. However, with this second procedure, tests interpretation is more complex, due to stress history effects (each stress sequence can possibly modify the subsequent results). 
BLANC, Juliette, GABET, Thomas, HORNYCH, Pierre, PIAU, Jean Michel, DI BENEDETTO, Hervé, 2015, Cyclic triaxial tests on bituminous mixtures , Road materials and pavement design, 1, 16, TAYLOR AND FRANCIS, pp.46-69, DOI: $10.1080 / 14680629.2014 .964293$

\section{Conventions and notations}

In general, the mean stress $p$ and the deviatoric stress $q$ are defined as:

$$
\left\{\begin{array}{c}
p=\operatorname{tr}(\Sigma) / 3 \\
q=\sqrt{\frac{3}{2} \operatorname{tr}\left(S^{2}\right)}
\end{array}\right.
$$

Where $S$ is the deviatoric part of $\Sigma$, the stress tensor, defined by $S=\sum-\frac{1}{3} \operatorname{tr}(\Sigma) I$.

In the case of the triaxial test, the mean stress $p$ and the deviatoric stress $q$ are:

$$
\left\{\begin{array}{l}
p=\frac{2 \sigma_{H}+\sigma_{V}}{3} \\
q=\left|\sigma_{V}-\sigma_{H}\right|
\end{array}\right.
$$

Where $\sigma_{H}$ is the horizontal stress and $\sigma_{V}$ is the vertical stress.

In this paper, the soil mechanics sign convention is used (positive stress/strain in compression/contraction).

In the particular case of the tests presented in this paper,

$\sigma_{V} \geq \sigma_{H} \geq 0$

so :

$$
q=\sigma_{V}-\sigma_{H}
$$

For the following, the axial or vertical stress is named $\sigma_{x}$ and the radial or horizontal stress is named $\sigma_{r}$.

During a triaxial cyclic test, a cyclic sinusoidal deviatoric stress $q$ and a constant confining pressure (or radial stress) $\sigma_{r}$ are applied to the specimen at the start of the test, and the evolutions of the axial and radial strains, $\varepsilon_{X}$ and $\varepsilon_{r}$, are measured.

Volumetric strains and deviatoric strains are deduced from axial and radial strains, using equations 6 and 7.

$$
\left\{\begin{array}{c}
\varepsilon_{V}=\varepsilon_{x}+2 \varepsilon_{r} \\
\varepsilon_{d}=\frac{2}{3}\left(\varepsilon_{x}-\varepsilon_{r}\right)
\end{array}\right.
$$




\section{Calculation of stress paths in pavement layers and determination of triaxial test conditions}

To define representative stress paths for the triaxial tests, pavement structure calculations have been performed with the pavement design software Alize LCPC (http://www.lcpc.fr/en/produits/alize/index.dml). Computations are based on a linear elastic model. The pavement layers are supposed isotropic, and infinite in the horizontal plane. Additional calculations have also been performed using a viscoelastic model, (Viscoroute software, Chabot et al., 2010 and Chupin et al., 2010). However, differences between the results were not significant, in terms of stress paths induced in the pavement. For brevity, only results of elastic simulations will be presented.

The simulations have been performed for a pavement structure consisting of $24 \mathrm{~cm}$ of dense-graded asphalt mix (DGAM) and $16 \mathrm{~cm}$ of road base asphalt (RBA) at $20^{\circ} \mathrm{C}$. $24 \mathrm{~cm}$ is not a realistic thickness for a bituminous layer, but it was used to highlight the influence of the thickness of the structure. The tire load is simulated by a circular surface, with a diameter of $25 \mathrm{~cm}$ and a contact pressure of $0.662 \mathrm{MPa}$ (see Figure 1).

Results are presented on Figure 1 and Figure 2. Figure 1 shows the values and signs of the vertical stress $\sigma_{\mathrm{V}}$ and horizontal (or radial) stress $\sigma_{\mathrm{H}}$ under the centre of the wheel:

- On the top of the pavement (A1), $\sigma_{\mathrm{V}}$ and $\sigma_{\mathrm{H}}$ are both in compression.

- At mid-depth in the pavement (A2), there is compression in the vertical direction and a small tension in the horizontal direction.

- At the bottom of the pavement (A3), there is compression in the vertical direction and tension in the horizontal direction (as shown by Heck, 2001).

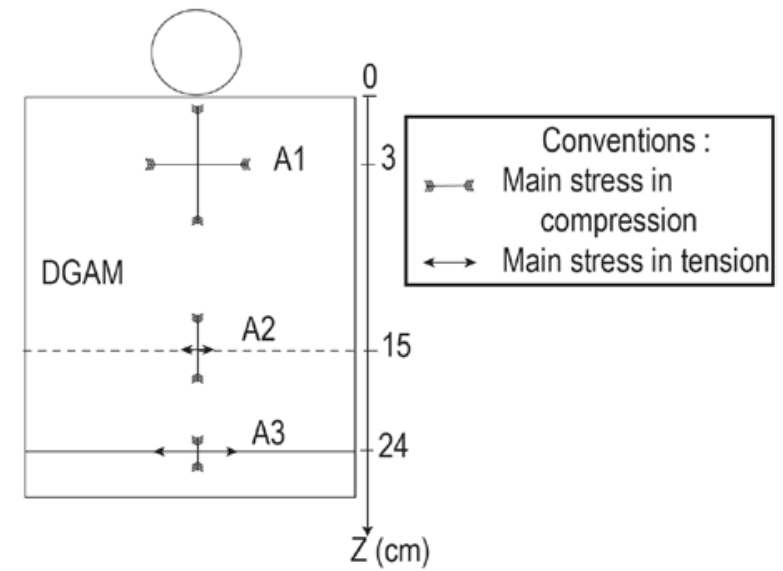

Figure 1. Stress states in a pavement layer under wheel loading

Figure 2 shows the stress paths produced, at different depths, by the moving load, in terms of mean stress $p$ and deviatoric stress $q$ (equations 1 and 2). 
BLANC, Juliette, GABET, Thomas, HORNYCH, Pierre, PIAU, Jean Michel, DI BENEDETTO, Hervé, 2015, Cyclic triaxial tests on bituminous mixtures, Road materials and pavement design, 1, 16, TAYLOR AND FRANCIS, pp.46-69, DOI: $10.1080 / 14680629.2014 .964293$

The stress paths induced in the structure have a complex shape, and range from compression at the top of the layer to tension, at the bottom, with a large range of q/p slopes (for this example from -2 to 3 ).

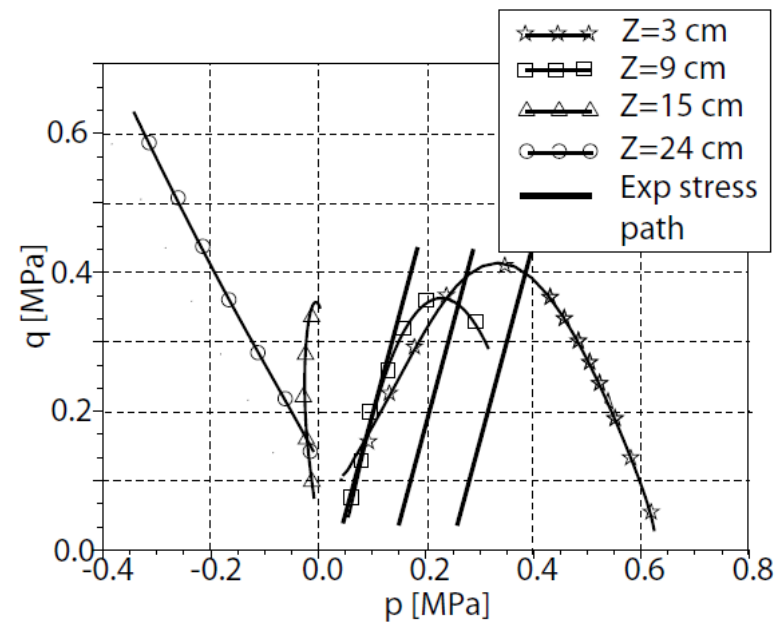

Figure 2. Stress paths at different depths $Z$ in bituminous layers and experimental stress path in the triaxial tests (solid line)

To simulate this range of stress paths during a cyclic triaxial test, it would be necessary to cycle both the axial load and the cell pressure. However, this requires a complex loading system, and for the IFSTTAR apparatus, it was decided to work, first, with a constant confining pressure, and to add the possibility of a variable confining pressure in a second phase. The experimental stress paths were thus limited to a constant slope $q / p=3$, and to stress states in compression $(p>0)$, as presented on figure 2 .

\section{Test equipment and material tested}

\subsection{Triaxial apparatus with temperature control}

The triaxial apparatus has been developed using an existing servo-hydraulic loading frame. The pressure cell, the temperature control system, and the instrumentation have been developed specifically for triaxial tests on bituminous mixtures (see figure 3 ).

The apparatus is designed for specimens with a diameter of $80 \mathrm{~mm}$ and a height of $160 \mathrm{~mm}$. The maximum axial load is $25 \mathrm{kN}$, the maximum confining pressure is $700 \mathrm{kPa}$, and the temperature range is from $5^{\circ} \mathrm{C}$ to $60^{\circ} \mathrm{C}$. Monotonic and cyclic axial loading can be applied, keeping a constant confining pressure. The maximum loading frequency is $10 \mathrm{~Hz}$. 


\subsubsection{Triaxial cell and loading frame}

The loading frame used to apply the axial load is a SCHENCK frame, with a servohydraulic actuator, with a load capacity of $\pm 100 \mathrm{kN}$ and a $\pm 100 \mathrm{~mm}$ axial stroke. The loading frame is equipped with a control system, which allows to perform a large range of loading tests (monotonic or cyclic) with load or displacement control. The triaxial cell for bituminous materials has been developed by GDS Instruments (see figure 3). It is made of aluminium, has an external diameter of $300 \mathrm{~mm}$, and can accept $80 \mathrm{~mm}$ or $100 \mathrm{~mm}$ diameter specimens. The confining fluid that is also used for temperature regulation can be water or air. Water ensures a better homogeneity of the temperature. The cell is equipped with an internal load transducer of $25 \mathrm{kN}$ capacity, and a $1000 \mathrm{kPa}$ pressure transducer, placed outside the cell, on the confining fluid supply circuit.

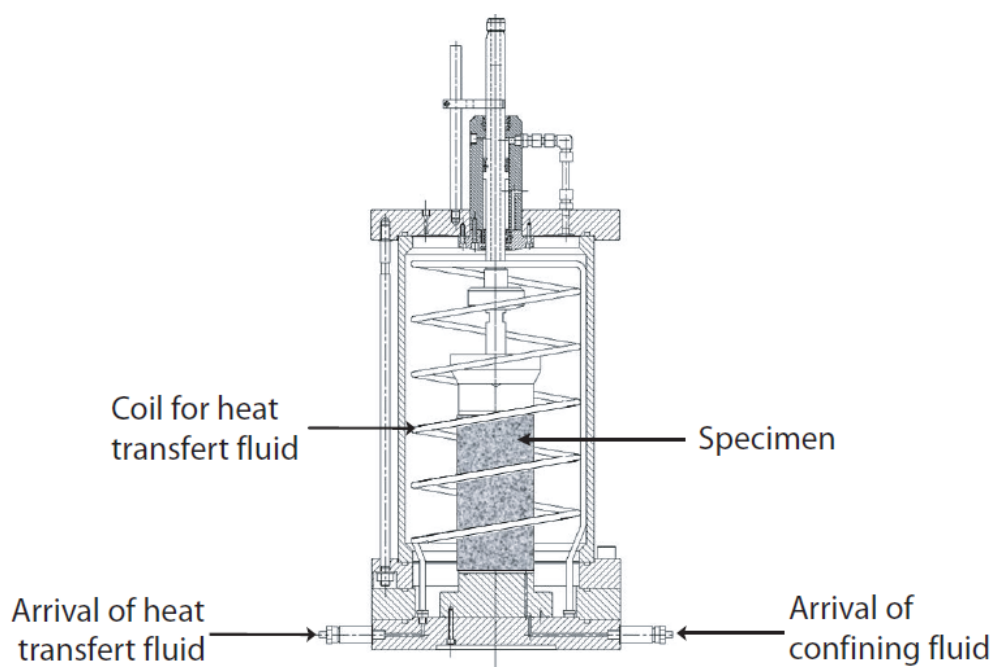

Figure 3. Scheme of the triaxial cell

\subsubsection{Temperature control system}

The temperature in the triaxial cell is regulated using a double heating and cooling system (figure 3). The first system consists of a coil, situated inside the triaxial cell, in which circulates the heating and cooling fluid (water with anti-freeze). This coil is connected with an external, removable heating and cooling system. To improve the control of the temperature in the cell, a thermal housing is added around the triaxial cell. A thermocouple placed inside the cell, at mid-height of the specimen is used to control the temperature.

To ensure stabilization of temperature before testing, specimens are stored in the triaxial cell at the testing temperature for at least 4 hours prior to testing. 


\subsection{Instrumentation}

Two kinds of sensors, placed on the central part of the specimen, are used in the tests:

- Strain gages are used to measure small strains, in a range of about 10 to 500 microstrains

- LVDT sensors are used to measure larger strains, corresponding to the permanent deformations of the material, which can reach up to 5 per cent of deformation.

\subsubsection{Strain gages}

The axial and radial small strains of the specimen are measured using four strain gages: two axial and two radial (see figure 4). The axial strains are measured on the central part of the specimen. The two radial gages are placed at mid-height of the specimen, along the circumference. The two gages are placed vertically, on opposite sides of the specimen. The average of the signals of the two gages is used to calculate the axial strain. The homogeneity of the strain field is also checked by comparing the values given by each sensor.

The gages have a measurement range of $1000 \mu \mathrm{def}$ and a resolution of $5 \mu \mathrm{def}$.

The procedure to glue the gages on the specimen is described in (Sohm, 2011) and (Gabet, 2006).

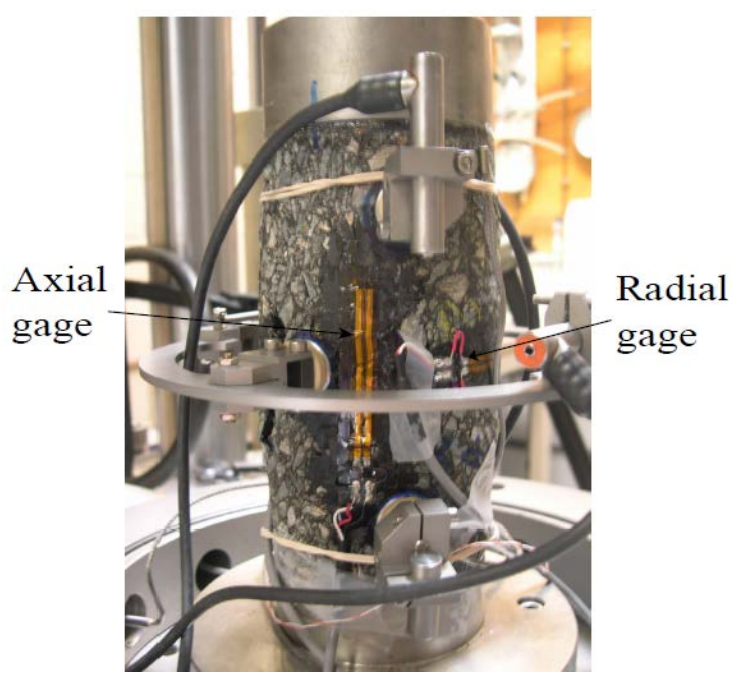

Figure 4. Axial and radial strain gages glued on a specimen (at the end of the test)

\subsubsection{Axial and radial displacement transducers}

The axial and radial strains of the specimen are also measured by means of LVDT sensors. The axial strains are measured on the central part of the specimen using two LVDTs, placed vertically, on opposite sides of the specimen (see Figure 5). The 
average of the signals of the two sensors is used to calculate the axial strain. The homogeneity of the strain field is also checked by comparing the values given by each sensor.

The radial strains are measured using an articulated ring, equipped with an LVDT, placed at mid-height of the specimen. The radial LVDT measures the opening of the ring, and thus the variations of the specimen diameter. The axial LVDTs and the articulated ring are glued on the specimen, using metallic clamps. The LVDTs have a measurement range of $5 \mathrm{~mm}$ and a resolution of $5 \mu \mathrm{m}$.

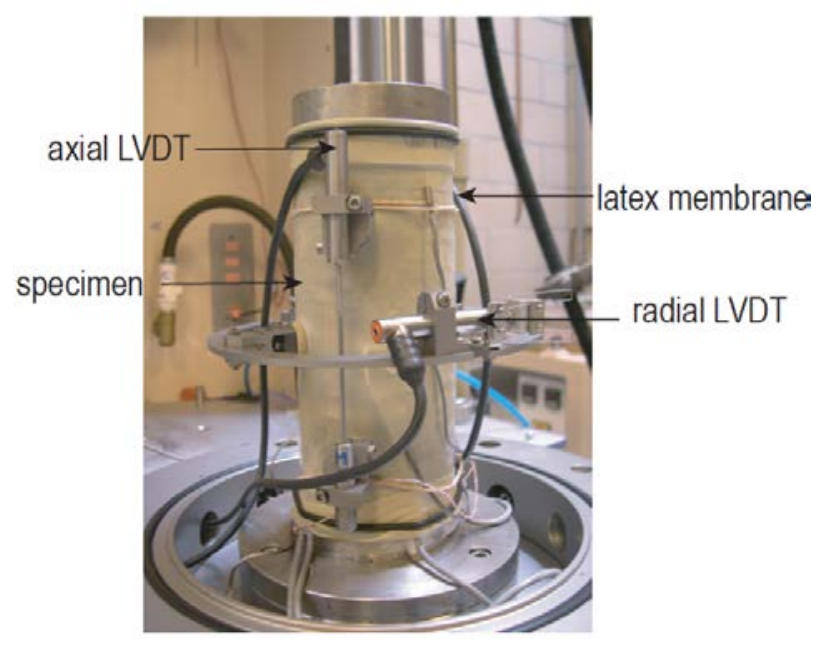

Figure 5. View of specimen with the axial and radial LVDT sensors

\subsection{Experimental procedures}

\subsubsection{Material and sample preparation}

The asphalt concrete tested in this study (using the triaxial apparatus) was a French $\mathrm{O} / 10 \mathrm{~mm}$ dense-graded bituminous mix, named BBSG or "Béton Bitumineux SemiGrenu”. This material is typically used for wearing courses in France. The characteristics of this mix are given in Table 1. It has been designed with a void percentage of $4.5 \%$. The void percentage was measured by a nuclear (gamma ray) method (EN 12 697-7). The mean of the void percentage, on 60 specimens, was $4.54 \%$ of voids and the standard deviation was $0.62 \%$ of voids $(13.6 \%$ in relative value).

Table 1. Characteristics of the tested bituminous mixture

\begin{tabular}{cc}
\hline Size of aggregates $(\mathrm{mm})$ & Percentage (by mass) \\
\hline $0 / 2$ & $27 \%$
\end{tabular}


BLANC, Juliette, GABET, Thomas, HORNYCH, Pierre, PIAU, Jean Michel, DI BENEDETTO, Hervé, 2015, Cyclic triaxial tests on bituminous mixtures, Road materials and pavement design, 1, 16, TAYLOR AND FRANCIS, pp.46-69, DOI: $10.1080 / 14680629.2014 .964293$

$\begin{array}{lr}2 / 4 & 10 \% \\ 4 / 6 & 25 \% \\ 6 / 10 & 35.5 \%\end{array}$

$6 / 10 \quad 35.5 \%$

Limestone filler $\quad 2.5 \%$

Penetration grade bitumen $\quad 50 / 70$

Bitumen percentage $\quad 5.50 \%$

Once mixed, the material is compacted using a slab compactor with rubber-tired wheels (EN 12697-33 + A1). The dimensions of the plates are $600 \mathrm{~mm}$ by $400 \mathrm{~mm}$ by $120 \mathrm{~mm}$ thick. After a minimum of two weeks of storage, 6 cylindrical specimens (80 $\mathrm{mm}$ in diameter and $160 \mathrm{~mm}$ high) were cored horizontally, from the central part of each slab. It would have been more relevant to core them vertically, in the compaction direction, but the thickness of the plates did not allow this. The specimens were stored in a room at a controlled temperature of $18^{\circ} \mathrm{C}$ before testing.

\subsubsection{Preparation of triaxial test specimen}

To perform tests in compression and tension, a metallic platen is glued to each end of the specimen. These platens are attached to the cell base and to the piston. To ensure homogeneity of the stress states in the specimen, a good alignment of the specimen and end platens is required. A specific stand, for gluing the end platens, has therefore been developed.

Then the LVDT clamps and the four strain gages are glued on the specimen. A latex membrane is placed around the specimen, above the clamps and finally, the LVDT sensors are fixed on the clamps (see figure 5).

\subsection{Standard mechanical characterisation of the asphalt concrete}

Two standard tests were made to characterize the bituminous mixture: the French wheel tracking test (WTT, large size device, $\mathrm{T}=60^{\circ} \mathrm{C}$, pressure of tyre is 6 bars and wheel frequency is $1 \mathrm{~Hz}$ ) (EN 12697-22) and the complex modulus test. The WTT test gives a rut depth of $7.2 \%$ at 30000 cycles. Rutting resistance of the chosen bituminous mixture is considered as medium. The complex modulus test is a twopoint bending test on a parallelepiped. The value of the norm of the complex modulus at $15^{\circ} \mathrm{C}$ and $10 \mathrm{~Hz}$ is $14400 \mathrm{MPa}$.

\section{Testing program and test data analysis}

\subsection{Description of the tests}

The aim of the experimental investigation is to study the influence of confining pressure and frequency on permanent deformations and viscoelastic properties of our material under cyclic loading. During a cyclic test, a cyclic sinusoidal deviatoric 
stress $q$ and a constant confining pressure (or radial stress) $\sigma_{r}$ are applied to the specimen at the start of the test, and the evolutions of the axial and radial strains, $\varepsilon_{x}$ and $\varepsilon_{r}$, are measured (see Figure 6).

The stress state is described using the mean stress $p$ and the deviatoric stress $q$. For axisymmetric triaxial test conditions, stresses are defined by equations 3 and 5 .
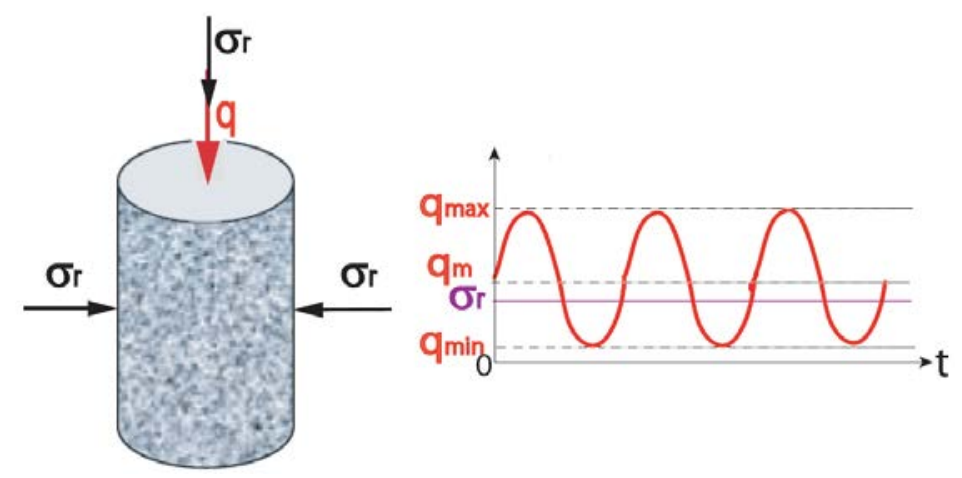

Figure 6. Principle of a cyclic triaxial test performed in this study. Definition of the variables $q$ and $\sigma_{r}$. The soil mechanics sign convention is used.

Two types of test procedures were used during the experimental program:

- $\quad$ First cyclic sinusoidal tests with successive load periods and rest periods, with fixed experimental conditions (frequency and confining pressure) all along the tests. These tests are named $\mathrm{T} 1$.

- $\quad$ Then cyclic sinusoidal test without rest periods, but with several successive loading phases at different frequencies and different confining pressures. These tests are named $\mathrm{T} 2$.

\subsubsection{Description of test procedure T1}

In this test procedure, cyclic compression and rest periods are successively applied leading to a high level of accumulated strain, outside the linear viscoelastic domain. The rest periods are used to measure the relaxation behaviour of the material after unloading. Applied stresses are presented in Figure 7 and table 2. 


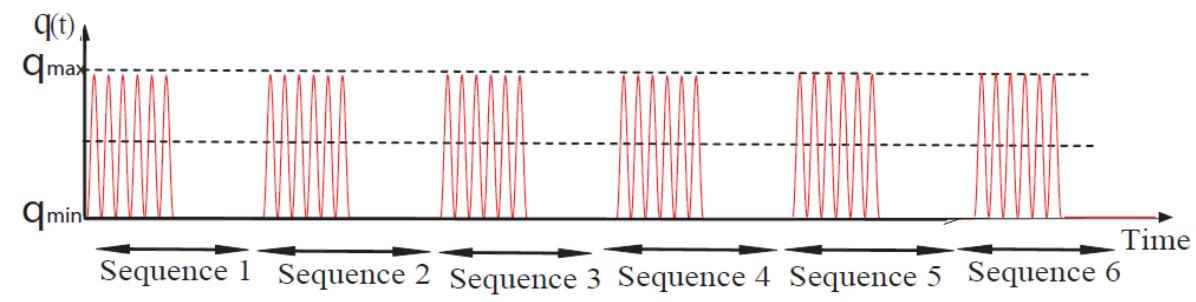

Figure 7. Applied stress sequences for tests $T 1$

Table 2. Load history for tests $T 1$

\begin{tabular}{|c|c|c|c|c|c|}
\hline & & \multicolumn{4}{|c|}{ frequency } \\
\hline & & \multicolumn{2}{|c|}{$1 \mathrm{~Hz}$} & \multicolumn{2}{|c|}{$10 \mathrm{~Hz}$} \\
\hline \multicolumn{2}{|c|}{ sequence } & Cycle & Time (s) & Cycle & Time (s) \\
\hline \multirow{2}{*}{1} & load & 30 & 30 & 300 & 30 \\
\hline & rest & 0 & 120 & 0 & 120 \\
\hline \multirow{2}{*}{2} & load & 100 & 100 & 1000 & 100 \\
\hline & rest & 0 & 400 & 0 & 400 \\
\hline \multirow{2}{*}{3} & load & 300 & 300 & 3000 & 300 \\
\hline & rest & 0 & 1200 & 0 & 1200 \\
\hline \multirow{2}{*}{4} & load & 1000 & 1000 & 10000 & 1000 \\
\hline & rest & 0 & 4000 & 0 & 4000 \\
\hline \multirow{2}{*}{5} & load & 3000 & 3000 & 30000 & 3000 \\
\hline & rest & 0 & 12000 & 0 & 12000 \\
\hline \multirow{2}{*}{6} & load & 10000 & 10000 & 100000 & 10000 \\
\hline & rest & 0 & 40000 & 0 & 40000 \\
\hline
\end{tabular}

\subsubsection{Description of test procedure T2}

With the test procedure $\mathrm{T} 1$ presented above, studying the influence of the load frequency or the confinement presents some difficulties in terms of repeatability, because each experimental condition is applied on a different specimen. As two specimens are never exactly identical, mainly due to manufacturing (in particular void content variations), it is sometimes difficult to know if differences between results are due to changing parameters between tests or to specimen variability. The aim of the test procedure $\mathrm{T} 2$ was to overcome repeatability problems due to manufacturing, by applying variable experimental conditions (different confining pressures or loading frequencies) in a single test. Three tests were performed according to procedure $\mathrm{T} 2$. In the first test (T2-1), the variable parameter was the 
confining pressure. The temperature, the cyclic deviatoric load and the frequency were kept constant all along the test. In the tests T2-2 and T2-3, the variable parameter was the frequency. In each test, several phases were set up. Tests are presented in detail in paragraph 5.2.2.

\subsection{Experimental program}

\subsubsection{Tests using procedure $T 1$}

A synthesis of all the tests T1 performed in this study is presented in Table 3. For all $\mathrm{T} 1$ tests, the temperature is $20^{\circ} \mathrm{C}$. The values of $q_{\min }$ and $q_{\max }$ are $: q_{\min }=60 \mathrm{kPa}$ and $q_{\max }=460 \mathrm{kPa}$. So the mean deviatoric stress $q_{m}$ is $260 \mathrm{kPa}$ and the amplitude of the sinusoidal deviatoric stress is $200 \mathrm{kPa}$.

Table 3. Synthesis of tests $T 1$

\begin{tabular}{ccccc}
\hline Test & $\sigma_{\mathrm{r}}$ & Frequency & $\begin{array}{c}\text { Material } \\
\text { plate }\end{array}$ & Void content \\
\hline & $\mathrm{kPa}$ & $\mathrm{Hz}$ & & $\%$ \\
1 & 0 & 1 & 11 & 5.3 \\
2 & 100 & 1 & 12 & 4.5 \\
3 & 100 & 1 & 12 & 4.6 \\
4 & 200 & 1 & 11 & 4.9 \\
5 & 100 & 1 & 11 & 5.7 \\
6 & 100 & 10 & 12 & 4.2 \\
\hline
\end{tabular}

\subsubsection{Tests using procedure $T 2$}

The test T2-1 included 3 phases. Each phase consisted of 5 loading sequences, with increasing confining pressures $\left(\sigma_{r}=0,50,100,200\right.$ or $\left.400 \mathrm{kPa}\right)$. The stress states applied during this test are shown in figure 8. The tests T2-2 and T2-3 included 4 phases. Each phase consisted of 5 loading sequences, with increasing load frequencies ( $f=0$ (creep), 1, 2, 5 and $10 \mathrm{~Hz}$ ). The confining pressure was different in the two tests. The stress states applied during these tests are presented in figure 9. The characteristics of each test are summarized in table 4 .

For the three tests using procedure T2, the values of $q_{\min }$ and $q_{\max }$ are $: q_{\min }=60 \mathrm{kPa}$ and $q_{\max }=460 \mathrm{kPa}$. So the mean deviatoric stress $q_{m}$ is $260 \mathrm{kPa}$ and the amplitude of the sinusoidal deviatoric stress is $200 \mathrm{kPa}$. For the two tests with creep phases, $q_{m}$ is also $260 \mathrm{kPa}$. 
BLANC, Juliette, GABET, Thomas, HORNYCH, Pierre, PIAU, Jean Michel, DI BENEDETTO, Hervé, 2015, Cyclic triaxial tests on bituminous mixtures, Road materials and pavement design, 1, 16, TAYLOR AND FRANCIS, pp.46-69, DOI: $10.1080 / 14680629.2014 .964293$

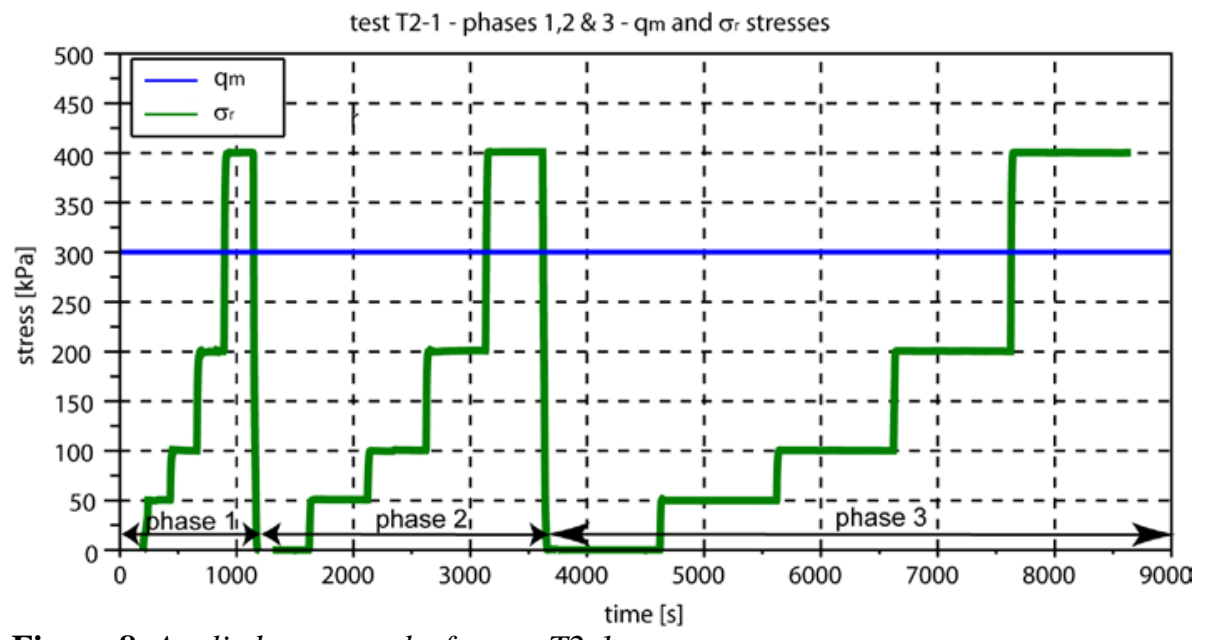

Figure 8. Applied stress paths for test T2-1 

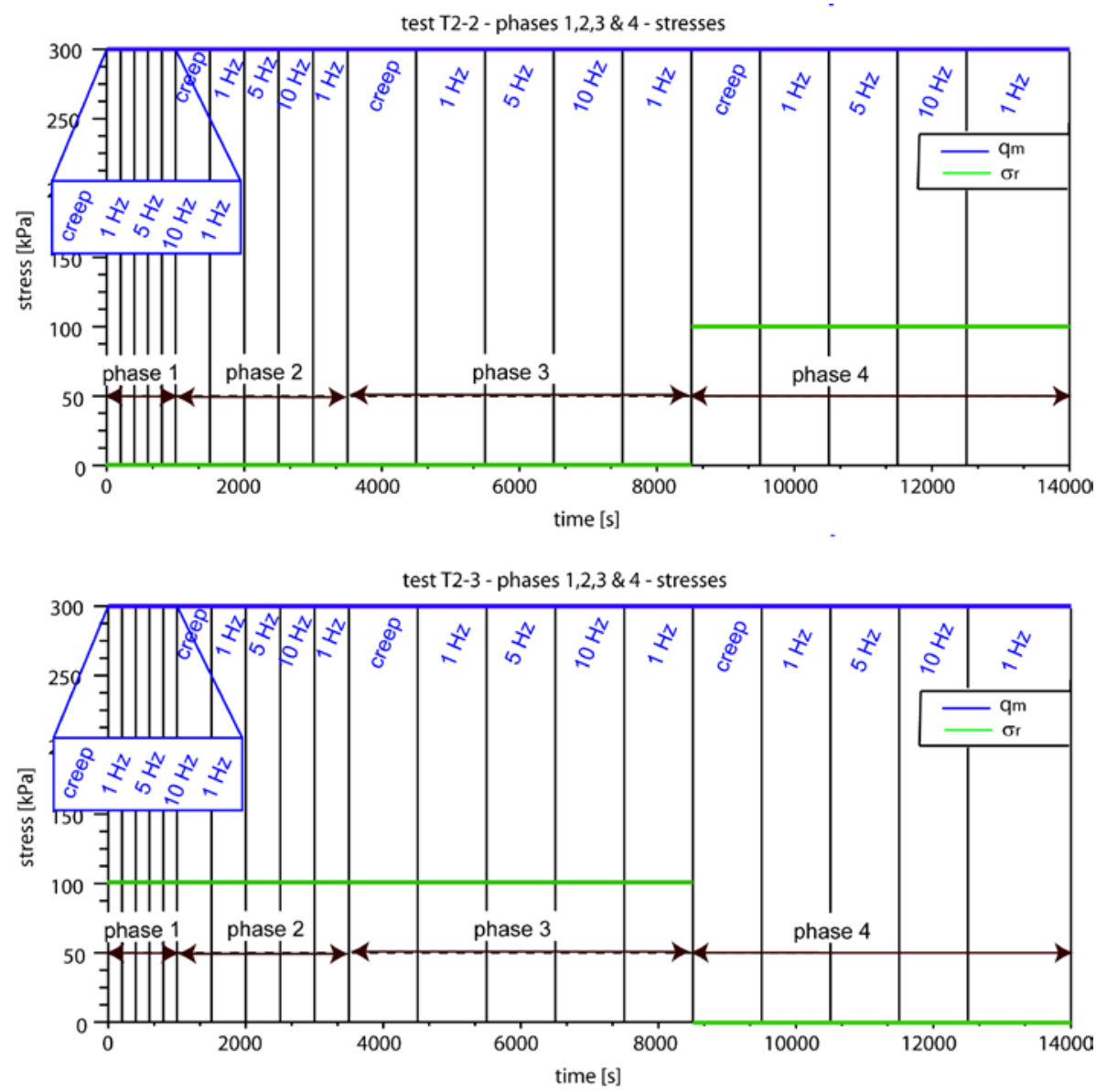

Figure 9. Applied stress paths for test T2-2 and T2-3

Table 4. Tests performed in this study according to procedure $T 2$

\begin{tabular}{|c|c|c|c|c|c|}
\hline & $\begin{array}{c}\text { Phase } \\
\text { modality duration (s) }\end{array}$ & $\begin{array}{l}\text { Phase } 1 \\
200(x 5)\end{array}$ & $\begin{array}{l}\text { Phase } 2 \\
500(x 5)\end{array}$ & $\begin{array}{c}\text { Phase } 3 \\
1000(x 5)\end{array}$ & $\begin{array}{l}\text { Phase } 4 \\
1000(x 5)\end{array}$ \\
\hline T2-1 & $\begin{array}{c}\text { confinement }(\mathrm{kPa}) \\
\text { frequency }(\mathrm{Hz})\end{array}$ & $\begin{array}{c}0-50-100-200-400 \\
1\end{array}$ & $\begin{array}{c}0-50-100-200-400 \\
1\end{array}$ & $\begin{array}{c}0-50-100-200-400 \\
1\end{array}$ & $\begin{array}{l}\text { II } \\
\text { /I }\end{array}$ \\
\hline T2-2 & $\begin{array}{c}\text { confinement }(\mathrm{kPa}) \\
\text { frequency }(\mathrm{Hz})\end{array}$ & $\begin{array}{c}0 \\
0 \text { (creep)-1-5-10-1 }\end{array}$ & $\begin{array}{c}0 \\
0 \text { (creep)-1-5-10-1 }\end{array}$ & $\begin{array}{c}0 \\
\text { O(creep)-1-5-10-1 }\end{array}$ & $\begin{array}{c}100 \\
\text { O(creep)-1-5-10-1 }\end{array}$ \\
\hline T2-3 & $\begin{array}{c}\text { confinement }(\mathrm{kPa}) \\
\text { frequency }(\mathrm{Hz})\end{array}$ & $\begin{array}{c}100 \\
0 \text { (creep)-1-5-10-1 }\end{array}$ & $\begin{array}{c}100 \\
\text { 0(creep)-1-5-10-1 }\end{array}$ & $\begin{array}{c}100 \\
0 \text { (creep)-1-5-10-1 }\end{array}$ & $\begin{array}{c}0 \\
0 \text { (creep)-1-5-10-1 }\end{array}$ \\
\hline
\end{tabular}

In test $\mathrm{T} 2-2$, the main parameter studied was the loading frequency, but in phase 4 , the confinement was increased to $100 \mathrm{kPa}$, to have also an idea of the influence of variable frequencies under confinement. As this change was made at the end of the 
BLANC, Juliette, GABET, Thomas, HORNYCH, Pierre, PIAU, Jean Michel, DI BENEDETTO, Hervé, 2015, Cyclic triaxial tests on bituminous mixtures, Road materials and pavement design, 1, 16, TAYLOR AND FRANCIS, pp.46-69, DOI: $10.1080 / 14680629.2014 .964293$

test, it was then decided to perform another test T2-3, with confinement applied at the beginning of the test.

The three samples have been cored in the same plate. The void ratio are respectively $4.4 \%, 4.7 \%$ and $5.0 \%$ for the 3 samples.

The analysis of the results of these tests is made in terms of cyclic strain amplitude (determination of complex modulus and Poisson ratio) and in terms of mean strain rate (evolution of viscoplastic strains). In paragraph 4.3, the sinusoidal regression used for analyzing data in terms of cyclic strain amplitude is presented. In paragraph 4.4, the method for studying strain rates discontinuities is presented.

\subsection{Sinusoidal regression for analyzing test data}

Each cyclic test represents a large quantity of data. About 10 signals are saved at the same time (load, vertical displacement, confining pressure, local axial and radial strains). A test at $10 \mathrm{~Hz}$, lasting 10000 seconds (around 3 hours) is considered. If 100 points per cycle are recorded, this will lead to a file with 10 million lines. It was decided to limit the amount of data by modelling solicitations and responses. As both solicitation and response are supposed to be sinusoidal, a sinusoidal regression was used to fit the experimental data. This allowed to decrease the amount of stored data and to calculate for each cycle the mean value and amplitude of each signal. From these values, complex modulus and permanent deformations could be determined.

The evolution with time of the deviatoric stress was fitted with the following function:

$$
q(t)=q(\tau, N)=q_{m}(N)+q_{0}(N) \sin (\omega \tau)=q_{m}(N)+\operatorname{Im}\left\{q_{0}(N) e^{i \omega \tau}\right\}
$$

Where :

- $\mathrm{T}$ is the period of the cyclic loading and $\omega=2 \pi / T$ the angular frequency

- $\mathrm{N}$ is the cycle number

- $\tau$ is the local time within the cycle number $\mathrm{N}, \tau=t-(N-1) T, 0 \leq \tau \leq T$

- $q_{0}(N)$ is the amplitude of the sinusoidal deviatoric stress

- $q_{m}(N)$ is the mean deviatoric stress

The measured axial and radial strains oscillate around a mean non-linear deformation curve (see figure 10). Evolutions with time (for two consecutive cycles) of these strains were fitted using the following functions ((Dongmo, 2005), (Neifar, 1997) and (Kappl and Blab, 2009)): 
$\left\{\begin{array}{l}\varepsilon_{x}(t)=\varepsilon_{x}(\tau, N)=\varepsilon_{x m}(N)+\alpha_{x}(N) \tau+\varepsilon_{x 0}(N) \sin \left(\omega \tau+\varphi_{x}(N)\right) \\ =\varepsilon_{x m}(N)+\alpha_{x}(N) \tau+\operatorname{Im}\left\{\varepsilon_{x 0}^{*}(N) e^{i \omega \tau}\right\} \\ \varepsilon_{r}(t)=\varepsilon_{r}(\tau, N)=\varepsilon_{r m}(N)+\alpha_{r}(N) \tau+\varepsilon_{r 0}(N) \sin \left(\omega \tau+\varphi_{r}(N)\right) \\ =\varepsilon_{r m}(N)+\alpha_{r}(N) \tau+\operatorname{Im}\left\{\varepsilon_{r 0}^{*}(N) e^{i \omega \tau}\right\}\end{array}\right.$

With $\varepsilon_{x 0}^{*}(N)=\varepsilon_{x 0}(N) e^{i \varphi_{x}(N)}$ and $\varepsilon_{r 0}^{*}(N)=\varepsilon_{r 0}(N) e^{i \varphi_{r}(N)-\pi}$

Where:

- $\varepsilon_{x 0}(N)$ and $\varepsilon_{r 0}(N)$ are the amplitudes of the sinusoidal axial and radial strains at cycle $\mathrm{N}$

- $\varepsilon_{x m}(N)$ and $\varepsilon_{r m}(N)$ are defined as the permanent deformations at cycle $\mathrm{N}$

- $\alpha_{x}(N)$ and $\alpha_{r}(N)$ are the axial and radial strain slopes at cycle $\mathrm{N}$

- $\varphi_{x}(N)$ and $\varphi_{r}(N)$ are the phase lags between the axial and radial strains and the axial stress at cycle $\mathrm{N}$, which are not considered as equal.

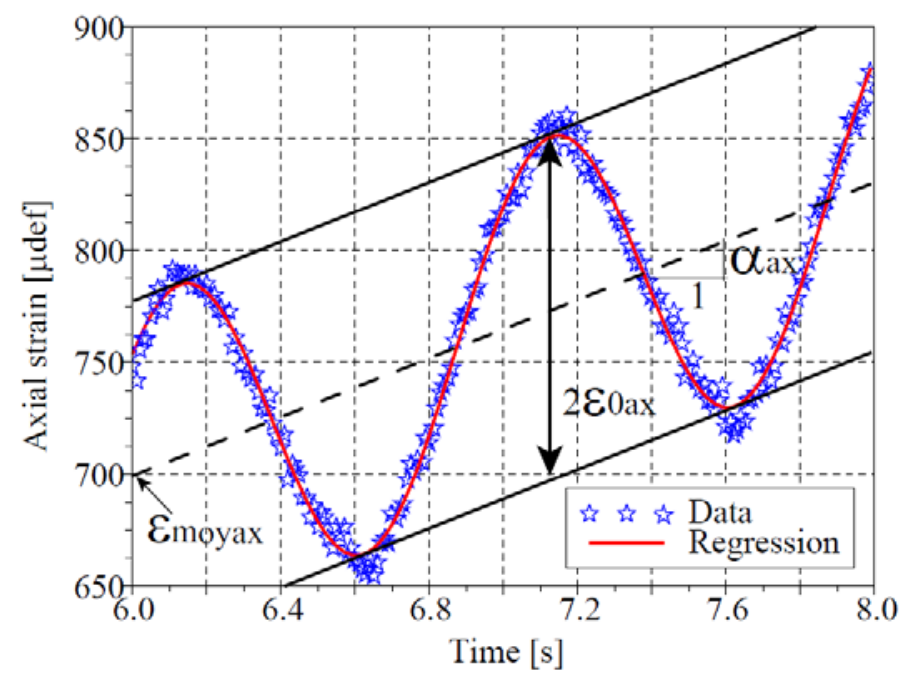

Figure 10. Analysis of experimental data. Sinusoidal regression.

The equations for the complex modulus and the complex Poisson ratio are:

$E^{*}(\omega)=\left|E^{*}\right| e^{i \varphi}=\frac{q_{0}(t)}{\varepsilon_{x 0}^{*}(t)}$ 
BLANC, Juliette, GABET, Thomas, HORNYCH, Pierre, PIAU, Jean Michel, DI BENEDETTO, Hervé, 2015, Cyclic triaxial tests on bituminous mixtures, Road materials and pavement design, 1, 16, TAYLOR AND FRANCIS, pp.46-69, DOI: $10.1080 / 14680629.2014 .964293$

$v^{*}(\omega)=\left|v^{*}\right| e^{i \varphi_{\nu}}=\frac{\varepsilon_{r 0}^{*}(N)}{\varepsilon_{x 0}^{*}(N)}=\frac{\varepsilon_{r 0}}{\varepsilon_{x 0}} e^{i(\varphi r-\varphi x-\pi)}$

Where :

- $\left|E^{*}\right|$ and $\left|v^{*}\right|$ are the norms of the complex modulus and Poisson ratio.

- $\varphi$ and $\varphi_{v}$ are the phase angles of the complex modulus and Poisson ratio.

- $q_{0}$ is the amplitude of the sinusoidal deviatoric stress

- $\varepsilon_{x 0}$ and $\varepsilon_{r 0}$ are the amplitudes of the sinusoidal axial and radial strains

- $\varphi_{x}$ and $\varphi_{r}$ are the phase lags between the axial and radial strains and the axial stress.

It is important to emphasize that for the stress levels applied, the amplitude of the sinusoidal axial strain is more than $10^{-4} \mathrm{~m} / \mathrm{m}$. According to Airey et al. (2003) and Airey et al. (2004), beyond this level, the behaviour of the bituminous mixture cannot be considered linear viscoelastic anymore. So, the modulus calculated in the following is not a true complex modulus.

\subsection{Regression for strain rate discontinuity analyses}

The principle of the strain rate analysis is presented in Figure 11. In this figure, a part of the axial response $\varepsilon_{m}$ of the test T2-2 is presented. The mean axial strain is a function of time. At time $t=1500 \mathrm{~s}$, the frequency is changed from $\mathrm{f}=0 \mathrm{~Hz}$ (creep) to $\mathrm{f}=1 \mathrm{~Hz}$. The experimental points of the axial strain clearly show a discontinuity in the slope at this time. The analysis consists in assessing the mean strain rate discontinuity at this time. The relative strain rate discontinuity $\Delta \dot{\varepsilon}_{x m}^{t i}$ at time $t i$ is defined as follows:

$$
\Delta \dot{\varepsilon}_{x m}^{t i}(\%)=\frac{\dot{\varepsilon}_{x m}^{t i+}-\dot{\varepsilon}_{x m}^{t i-}}{\frac{1}{2}\left(\dot{\varepsilon}_{x m}^{t i+}+\dot{\varepsilon}_{x m}^{t i-}\right)} \cdot 100
$$

$\dot{\varepsilon}_{x m}^{t^{+}}$and $\dot{\varepsilon}_{x m}^{t i-}$ are determined from polynomial regressions fitted on the values of the axial mean strain function of time, before and after the discontinuity respectively. The axial mean strain $\varepsilon_{x m}(N)$ is obtained using equation [9]. It has to be noticed that it is necessary to assess this discontinuity without regression because of some scatter in the experimental data.

The authors would point out that in tests T2, considering the viscoplastic strain, it has no sense to consider the total accumulated strains (from the beginning to the end of the test) because loading modalities change several times during the test. At 
each modality change (confinement or frequency), a focus is made on the strain rate discontinuity, defined in equation [10].

Test T2-2, phase 1.

Changing frequency at $t=1500 \mathrm{~s}$, from creep test to $\mathrm{f}=1 \mathrm{~Hz}$

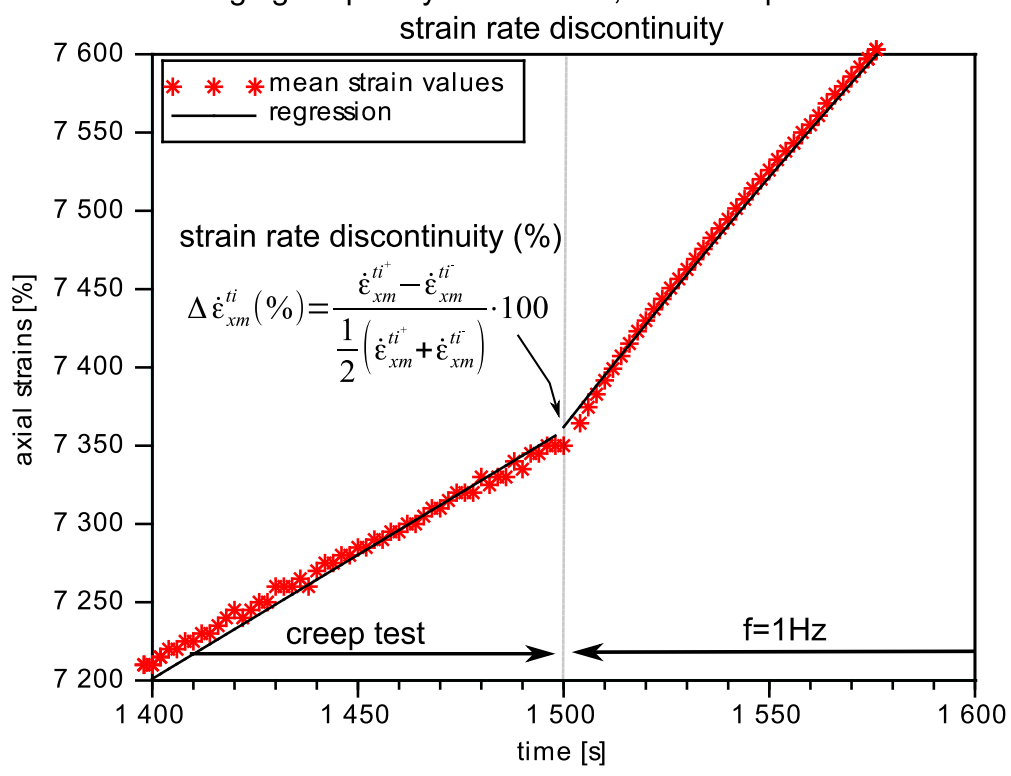

Figure 6. Strain rate analysis. Definition of the strain rate discontinuity at the time $t=1500 \mathrm{sec}$, where frequency is changed from $f=0 \mathrm{~Hz}$ (creep test) to $f=1 \mathrm{~Hz}$.

\section{Results}

\subsection{Repeatability of triaxial cyclic sinusoidal compression tests (T1)}

A triaxial cyclic sinusoidal compression test, made at $\mathrm{T}=20^{\circ} \mathrm{C}, \mathrm{q}_{\mathrm{m}}=260 \mathrm{kPa}$, $\sigma_{\mathrm{r}}=100 \mathrm{kPa}$ and $\mathrm{f}=1 \mathrm{~Hz}$, was repeated 3 times.

Test 2 and test 3 were made on two samples coming from the same manufactured plate. Test 5 was made on a sample cored from another plate. Their void contents were respectively $4.5 \%, 4.6 \%$ and $5.7 \%$. 
BLANC, Juliette, GABET, Thomas, HORNYCH, Pierre, PIAU, Jean Michel, DI BENEDETTO, Hervé, 2015, Cyclic triaxial tests on bituminous mixtures, Road materials and pavement design, 1, 16, TAYLOR AND FRANCIS, pp.46-69, DOI: $10.1080 / 14680629.2014 .964293$

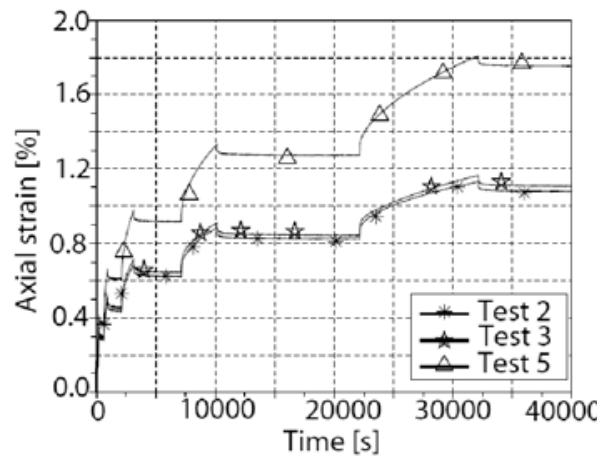

a)

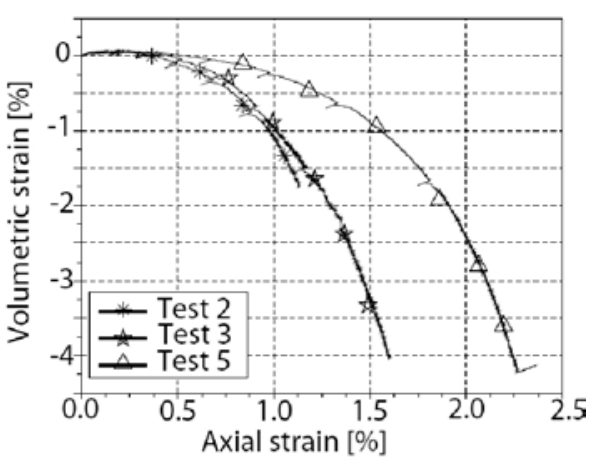

b)

Figure 7. a) Axial strain function of time and b) volumetric strain function of axial strain, for the three repeatability tests

Figure 12a presents the axial strain function of time for the three repeatability tests. For tests 2 and 3 (cored in the same plate), axial and volumetric strains are very close. For test 5, axial strain is 25\% more important than for tests 2 and 3 . They clearly have different kinetics.

Figure 12b presents the volumetric strain as a function of axial strain. For the three tests, volumetric strain is slightly contractant at low strain level, and then strongly dilatant at higher strain levels. These results tend to show that a denser bituminous mixture (test 2 and 3 ) is less deformable (referring to axial strains) and more dilatant than a less dense one (test 5).

Presently, it is difficult to assess if the differences observed are due only to different densities or more generally to the different origins of the specimens. More repeatability tests should clearly be performed, but the results show that using specimens cored in the same plate reduces the scatter of the results.

During these three tests, complex modulus and Poisson ratio were also measured. For the three tests, mean values were very close, with a standard deviation of $5 \%$, except for the phase angle of the Poisson ratio, which value is very low (about $-3^{\circ}$ ) (see table 5). Repeatability problems seem to be less important for complex modulus than for permanent deformations. It is also interesting to note that the density variations between the specimens did not affect the viscoelastic properties.

Table 5. Standard deviation of complex modulus and Poisson ratio and their phase angle

\begin{tabular}{l|l}
\hline & Standard deviation \\
$\left|E^{*}\right|$ & $1.8 \%$ \\
$\varphi$ & $0.9 \%$ \\
\hline
\end{tabular}




\begin{tabular}{l|l}
\hline$\left|v^{*}\right|$ & $2.2 \%$ \\
$\varphi_{v}$ & $17.7 \%$ \\
\hline
\end{tabular}

\subsection{Loading and unloading behaviour (T1)}

In order to separate the recoverable and irrecoverable strains, rest periods were applied at the end of each loading phase. During the rest periods, the deviatoric stress $q$ was not set to 0 (due to constraints of the servo-hydraulic loading system) but to $60 \mathrm{kPa}$. The strains were measured during these "recovery" phases.

An example of strain response during loading and unloading, for the test at $\mathrm{q}_{\mathrm{m}}=260 \mathrm{kPa}, \sigma_{\mathrm{r}}=100 \mathrm{kPa}, \mathrm{T}=20^{\circ} \mathrm{C}$ and $\mathrm{f}=1 \mathrm{~Hz}$ (test 2) is shown in figure 13 .

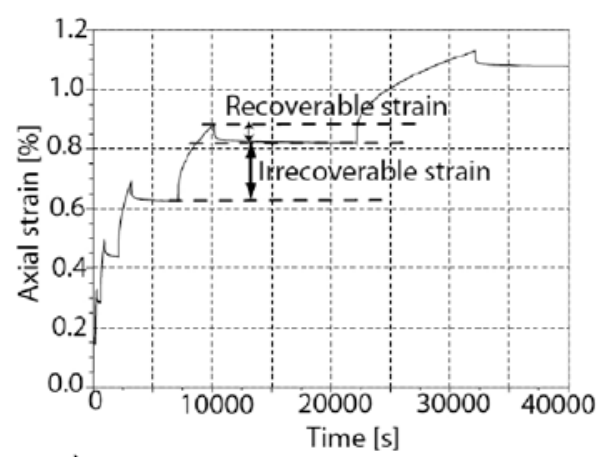

a)

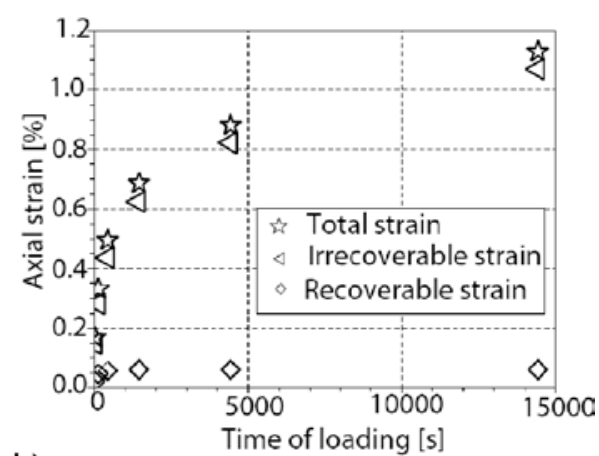

b)

Figure 83. a) Loading and unloading phases, for test 2; b) Part of irrecoverable and recoverable strains

It can be seen that the resilient strain after unloading is very small compared to the irrecoverable strain. The results were similar in all tests, the recoverable strain never exceeds $6 \%$ of the total strain. Dongmo (2005) has already presented similar conclusions, without confining pressure.

\subsection{Influence of the confining pressure on cyclic response}

\subsubsection{Influence on permanent deformations : test procedure $T 1$}

Three tests with procedure $\mathrm{T} 1$ have been performed at $20^{\circ} \mathrm{C}, 1 \mathrm{~Hz}$, at a mean deviatoric stress of $\mathrm{q}_{\mathrm{m}}=260 \mathrm{kPa}$ and at three different confining pressures: 0,100 and $200 \mathrm{kPa}$. The three specimens were cored in the same plate, in order to limit problems of repeatability. The results of these tests are presented in Figure 14a, b and c. They show that increasing the confining pressure reduces the axial and radial strains. Figure 14d represents the volumetric strain function of axial strain. The test 
BLANC, Juliette, GABET, Thomas, HORNYCH, Pierre, PIAU, Jean Michel, DI BENEDETTO, Hervé, 2015, Cyclic triaxial tests on bituminous mixtures, Road materials and pavement design, 1, 16, TAYLOR AND FRANCIS, pp.46-69, DOI: $10.1080 / 14680629.2014 .964293$

without confining pressure leads to the highest negative volumetric strains. The two tests with confining pressure lead to smaller negative strains.

This effect of the confining pressure clearly confirms the benefits of triaxial tests for understanding and modelling the permanent deformation behaviour. Behaviour observed in triaxial tests is clearly different from uniaxial behaviour: when a confinement is applied, it leads to a significant decrease of permanent strains, and a change of the volumetric behaviour; less dilatancy is observed when the confinement increases.

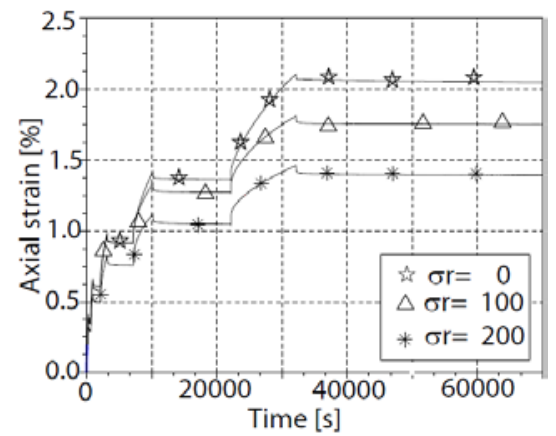

a)
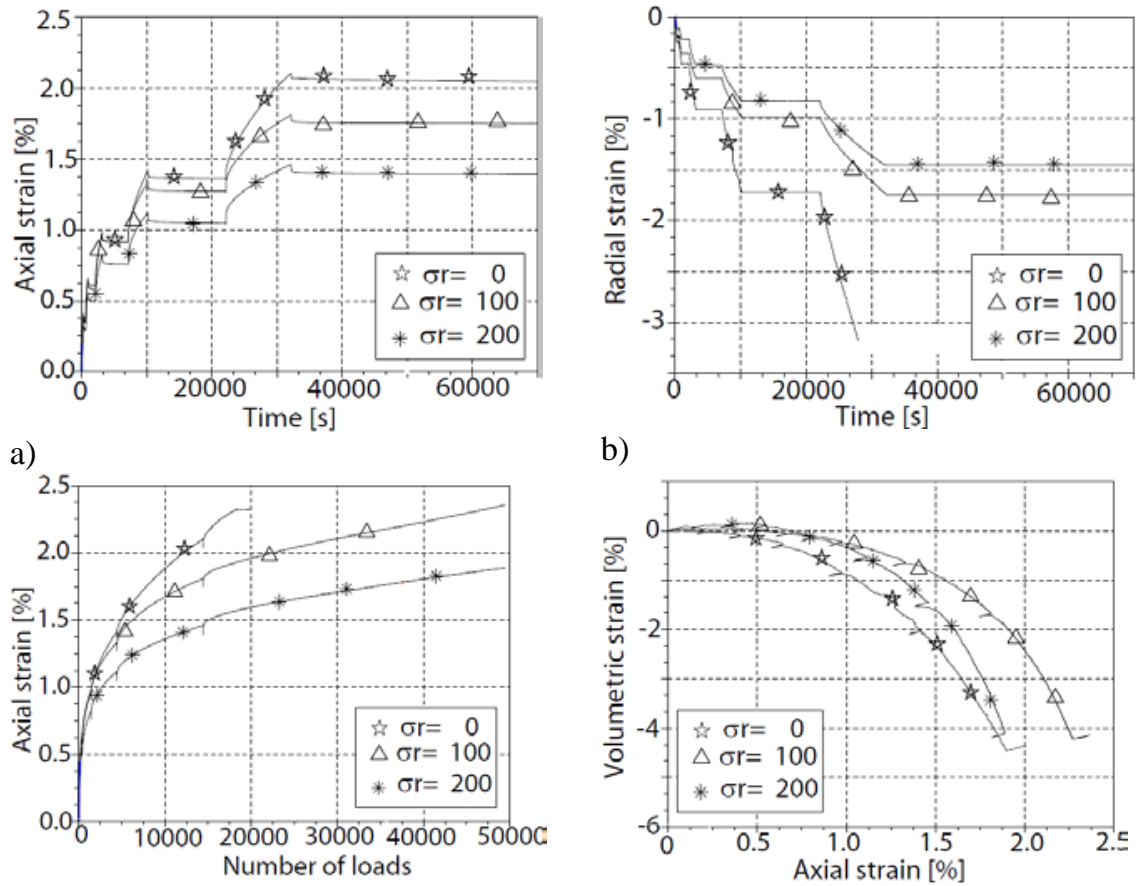

b)

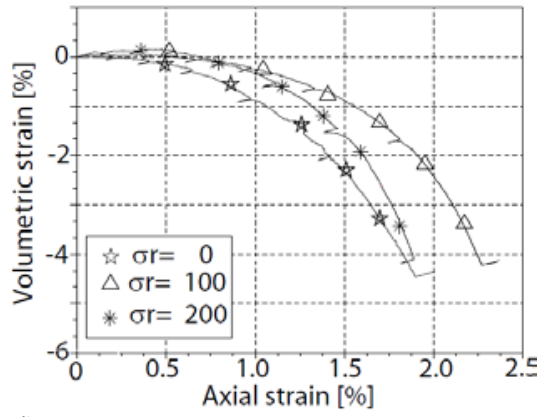

d)

Figure 94. a) Axial strains as a function of time; b) Radial strains as a function of time; c) Axial strains as a function of number of loads and d) volumetric strain as a function of axial strain, for tests at $20^{\circ} \mathrm{C}, 1 \mathrm{~Hz}, q_{m}=260 \mathrm{kPa}$ and different confinements

\subsubsection{Influence on strain rate : test procedure $T 2$}

In test T2-1, one sample was submitted to sinusoidal creep tests at different and successive confining pressures, to avoid problems of repeatability. The temperature $\left(20^{\circ} \mathrm{C}\right)$, the frequency $(1 \mathrm{~Hz})$ and the mean level of the deviatoric load $\left(\mathrm{q}_{\mathrm{m}}=260 \mathrm{kPa}\right)$ were maintained constant during the test. 
Results of test T2-1 are summarized in Table 6. Because the confining pressure was changed several times during this test, the analysis of the results is focussed on the strain rate discontinuity at each change of confining pressure. According to the results of tests $\mathrm{T} 1$, it is expected that an increase of confining pressure leads to a decrease of the strain rate. This trend is observed at each change of confinement in the first phase of the test and for most confinement levels in phases 2 and 3, except 3 contradictory results. These contradictory results can be observed for low confinement changes, in phase 2, from 0 to 50 and from 50 to $100 \mathrm{kPa}$, and in phase 3 , from 0 to $50 \mathrm{kPa}$. These contradictory results are difficult to explain, they may be due to an imprecise data fitting. But they could also be due to the fact that increasing the confinement also leads to increase the axial stress $\left(\sigma_{x}=\sigma_{r}+q\right)$. And it is thought that increasing both confinement and axial stress leads to opposite trends in term of strain rates.

In conclusion, we consider that results of tests $\mathrm{T} 1$ are confirmed because increasing significantly the confinement leads to decrease significantly the axial strain rate.

Table 6. Test conditions and results for test T2-1

\begin{tabular}{|c|c|c|c|}
\hline & \multicolumn{3}{|c|}{ test T2-1 } \\
\hline & $\begin{array}{l}\text { confinement } \\
\text { changing }\end{array}$ & $\begin{array}{l}\text { test time } \\
\text { (sec) }\end{array}$ & $\begin{array}{c}\text { strain rate } \\
\text { discontinuity at } \\
\text { test time }\end{array}$ \\
\hline \multirow{6}{*}{ phase 1} & start & 0 & $1 /$ \\
\hline & $0->50 \mathrm{MPa}$ & 225 & $-6 \%$ \\
\hline & $50->100 \mathrm{MPa}$ & 450 & $-10 \%$ \\
\hline & $100->200 \mathrm{MPa}$ & 675 & $-11 \%$ \\
\hline & $200->400 \mathrm{MPa}$ & 900 & $-15 \%$ \\
\hline & $400->0 \mathrm{MPa}$ & 1125 & $15 \%$ \\
\hline \multirow{5}{*}{ phase 2} & 0 -> $50 \mathrm{MPa}$ & 1625 & $4 \%$ \\
\hline & $50->100 \mathrm{MPa}$ & 2125 & $9 \%$ \\
\hline & 100 -> $200 \mathrm{MPa}$ & 2625 & $-5 \%$ \\
\hline & $200->400 \mathrm{MPa}$ & 3125 & $-18 \%$ \\
\hline & $400->0 \mathrm{MPa}$ & 3625 & $41 \%$ \\
\hline \multirow{5}{*}{ phase 3} & $0->50 \mathrm{MPa}$ & 4625 & $5 \%$ \\
\hline & $50->100 \mathrm{MPa}$ & 5625 & $-20 \%$ \\
\hline & $100->200 \mathrm{MPa}$ & 6625 & $-18 \%$ \\
\hline & $200->400 \mathrm{MPa}$ & 7625 & $-23 \%$ \\
\hline & stop & 8625 & $/ /$ \\
\hline
\end{tabular}

\subsubsection{Influence of confining pressure on viscoelastic properties}

Mean values of complex modulus, Poisson ratio and phase angle were calculated for each confining pressure and each loading phase. Results are presented in table 7. 
BLANC, Juliette, GABET, Thomas, HORNYCH, Pierre, PIAU, Jean Michel, DI BENEDETTO, Hervé, 2015, Cyclic triaxial tests on bituminous mixtures , Road materials and pavement design, 1, 16, TAYLOR AND FRANCIS, pp.46-69, DOI: $10.1080 / 14680629.2014 .964293$

Complex modulus is measured in laboratory, using a two point bending test on a parallelepiped. The value at $20^{\circ} \mathrm{C}$ and $1 \mathrm{~Hz}$ is $6630 \mathrm{MPa}$. That is close to the values measured during the cyclic sinusoidal test (T2-1).

Table 7. Values of complex modulus, Poisson ratio and phase angles, in function of confining pressure at $20^{\circ} \mathrm{C}, 1 \mathrm{~Hz}$.

\begin{tabular}{|c|c|c|c|c|c|}
\hline Phase & $\boldsymbol{\sigma}_{\text {rad }}$ & $\left|\mathbf{E}^{*}\right|$ & $\boldsymbol{\varphi}$ & $\left|\boldsymbol{v}^{*}\right|$ & $\boldsymbol{\varphi}_{\mathbf{v}}$ \\
\hline \multirow{5}{*}{1} & $0 \mathrm{kPa}$ & $5790 \mathrm{MPa}$ & $30.2^{\circ}$ & 0.31 & $-2.6^{\circ}$ \\
\cline { 2 - 6 } & $50 \mathrm{kPa}$ & $5840 \mathrm{MPa}$ & $29.4^{\circ}$ & 0.32 & $-2.6^{\circ}$ \\
\cline { 2 - 6 } & $100 \mathrm{kPa}$ & $5860 \mathrm{MPa}$ & $29.3^{\circ}$ & 0.32 & $-3.2^{\circ}$ \\
\cline { 2 - 6 } & $200 \mathrm{kPa}$ & $5860 \mathrm{MPa}$ & $28.8^{\circ}$ & 0.32 & $-3.1^{\circ}$ \\
\cline { 2 - 6 } & $400 \mathrm{kPa}$ & $5870 \mathrm{MPa}$ & $28.8^{\circ}$ & 0.32 & $-3.1^{\circ}$ \\
\hline \multirow{5}{*}{2} & $0 \mathrm{kPa}$ & $5850 \mathrm{MPa}$ & $29.2^{\circ}$ & 0.32 & $-2.5^{\circ}$ \\
\cline { 2 - 6 } & $50 \mathrm{kPa}$ & $5830 \mathrm{MPa}$ & $29.1^{\circ}$ & 0.32 & $-2.4^{\circ}$ \\
\cline { 2 - 6 } & $100 \mathrm{kPa}$ & $5830 \mathrm{MPa}$ & $29.1^{\circ}$ & 0.31 & $-2.5^{\circ}$ \\
\cline { 2 - 6 } & $200 \mathrm{kPa}$ & $5830 \mathrm{MPa}$ & $28.8^{\circ}$ & 0.32 & $-2.4^{\circ}$ \\
\cline { 2 - 6 } & $400 \mathrm{kPa}$ & $5880 \mathrm{MPa}$ & $28.6^{\circ}$ & 0.31 & $-2.2^{\circ}$ \\
\hline \multirow{5}{*}{3} & $0 \mathrm{kPa}$ & $5860 \mathrm{MPa}$ & $29.2^{\circ}$ & 0.31 & $-2.2^{\circ}$ \\
\cline { 2 - 6 } & $50 \mathrm{kPa}$ & $5830 \mathrm{MPa}$ & $29.2^{\circ}$ & 0.31 & $-2.3^{\circ}$ \\
\cline { 2 - 6 } & $100 \mathrm{kPa}$ & $5820 \mathrm{MPa}$ & $29.2^{\circ}$ & 0.31 & $-2.3^{\circ}$ \\
\cline { 2 - 6 } & $200 \mathrm{kPa}$ & $5860 \mathrm{MPa}$ & $29.0^{\circ}$ & 0.31 & $-2.3^{\circ}$ \\
\cline { 2 - 6 } & $400 \mathrm{kPa}$ & $5950 \mathrm{MPa}$ & $28.6^{\circ}$ & 0.31 & $-2.2^{\circ}$ \\
\hline
\end{tabular}

Values of complex modulus, Poisson ratio and phase angle remain practically the same for the 5 levels of confining pressures (from 0 to $400 \mathrm{kPa}$ ). There is no significant influence of the confining pressure on the viscoelastic properties of the tested bituminous mixture. These results confirm those obtained by Clec'h et al. (2009).

\subsection{Influence of loading frequency}

\subsubsection{Influence on permanent deformations: test procedure T1.}

Two tests have been performed at $20^{\circ} \mathrm{C}$, at a mean deviatoric stress of $\mathrm{q}_{\mathrm{m}}=260 \mathrm{kPa}$, at a confining pressure of $\sigma_{\mathrm{r}}=100 \mathrm{kPa}$, and at two different frequencies: $1 \mathrm{~Hz}$ and 10 $\mathrm{Hz}$. The two specimens were taken from the same plate.

Figures 15a and 15b show the axial and radial strains as functions of time. For the two frequencies, the axial strains are the same. Radial strains are slightly more important at $1 \mathrm{~Hz}$ than at $10 \mathrm{~Hz}$. These results were not really expected. 
Figures $15 \mathrm{c}$ and $15 \mathrm{~d}$ show the axial and radial strains as function of the number of load cycles. In this scale, axial and radial strains are much higher at $1 \mathrm{~Hz}$ than at $10 \mathrm{~Hz}$. This seems to indicate that the development of permanent strains depends much more on the loading rate, or on the total loading time than on the number of cycles (on figure 15a and 15b, multiplying the number of cycles by 10 does not change the results, provided that the loading time is the same).

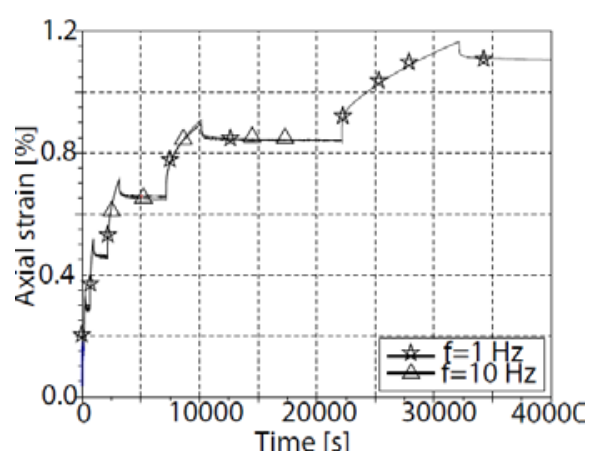

a)

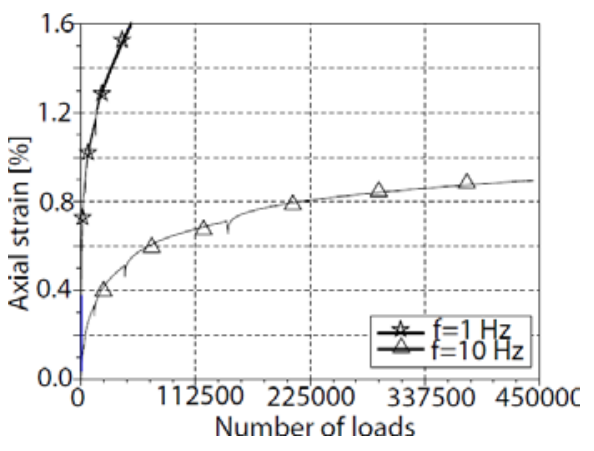

C)

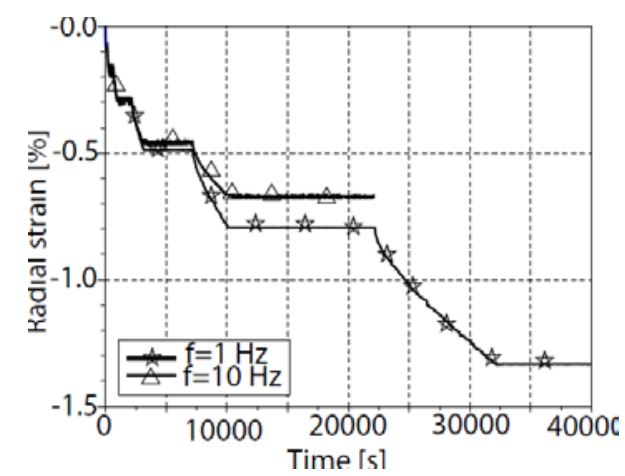

b)

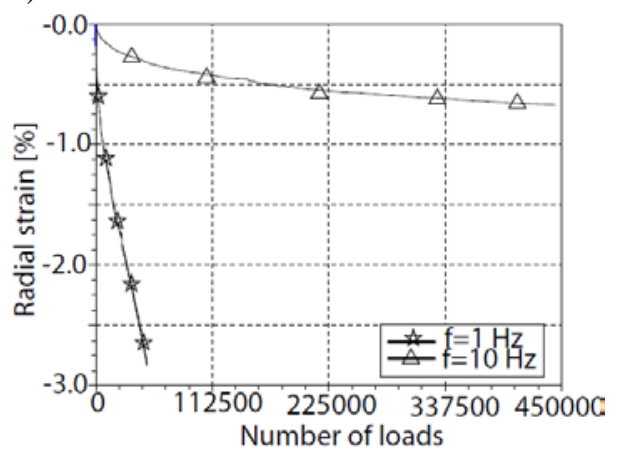

d)

Figure 10. a) Axial strains as a function of time; b) Radial strains as a function of time; c) Axial strains as a function of number of load cycles and d) Radial strains as a function of number of load cycles, for tests at $20^{\circ} \mathrm{C}, q_{\mathrm{m}}=260 \mathrm{kPa}, \sigma_{\mathrm{r}}=100 \mathrm{kPa}$ and different frequencies.

\subsubsection{Influence on permanent deformation: test procedure $T 2$}

Tests T2-2 and T2-3 were performed at $20^{\circ} \mathrm{C}$, at a mean deviatoric stress of $260 \mathrm{kPa}$ and a confining pressure of 0 or $100 \mathrm{kPa}$, depending on the testing phase (see Table 8). The objective was to analyse the effect of the frequency on the strain rate discontinuity. Results are presented in Table 8 . Whatever the test and loading phase, changing from a creep (static) solicitation to a cyclic solicitation leads to an 
BLANC, Juliette, GABET, Thomas, HORNYCH, Pierre, PIAU, Jean Michel, DI BENEDETTO, Hervé, 2015, Cyclic triaxial tests on bituminous mixtures, Road materials and pavement design, 1, 16, TAYLOR AND FRANCIS, pp.46-69, DOI: $10.1080 / 14680629.2014 .964293$

important increase of the strain rate. Then, under cyclic loading, increasing the frequency leads to a decrease of the strain rate. It is true when the frequency is increased from $1 \mathrm{~Hz}$ to $5 \mathrm{~Hz}$ and from $5 \mathrm{~Hz}$ to $10 \mathrm{~Hz}$. Decreasing the frequency, here from $10 \mathrm{~Hz}$ to $1 \mathrm{~Hz}$, always leads to a strong increase of the strain rate. All these strain rate variations are summarized in Table 9. A test at a frequency of $1 \mathrm{~Hz}$ leads to an axial strain rate $45 \%$ higher than a creep test; a test performed at a frequency of $1 \mathrm{~Hz}$ leads to an axial strain rate 30\% higher than a test performed at $10 \mathrm{~Hz}$.

According to these results, it is clear that changing frequency has an effect on permanent strain rate. This may be contradictory with the result presented in figure 15 a). Several explanations maybe proposed. As a first possible explanation, it is thought that the effect of changing frequency is temporary only, so that permanent deformation strains would be finally the same after a long loading time. However, this assumption is not in accordance with the results of the literature, without confining pressure (Dongmo, 2005). The second explanation considers that the two results presented in figure $15 \mathrm{a}$ ) are accidentally the same. The problems of repeatability of both tests may have lead to higher permanent strains value than usual at $10 \mathrm{~Hz}$ and/or lower permanent strains than usual at $1 \mathrm{~Hz}$, so that the expected influence of changing frequency could not be highlighted. We are convinced that some other tests would validate this hypothesis, which would more suit with the literature.

Explaining why cyclic loading leads to higher permanent deformations than creep loading is not obvious. The authors try to explain this by two reasons. Firstly, it is thought that cycling loads facilitates the relative movements of the grains (rotations, displacements) of the granular skeleton. It is secondly thought that cycling around a mean value necessarily lead to reach higher stress levels (in our tests, a mean value of $\mathrm{q}$ at $200 \mathrm{kPa}$ leads to reach $400 \mathrm{kPa}$ ). More plastic phenomenon may appear due to reached higher values and passed thresholds.

It would also be interesting to explain why lower frequencies lead to higher permanent deformations than higher frequencies. The authors think that for a given test duration, lower frequencies allows to remain at higher stress levels during longer periods (the time of a half cycle), which may more affect the material than reaching more often the higher level. It is thought that at lower frequency, higher viscoelastic strains are reached (see viscoelastic results), then relative movements of the grains of the granular skeleton are more important; this may facilitate the setting of irreversible (permanent strains). 
Table 8. Test conditions and results of tests $T 2-2$ and $T 2-3$

\begin{tabular}{|c|c|c|c|}
\hline & & test T2-2 & test T2-3 \\
\hline frequency changing & test time(sec) & \multicolumn{2}{|c|}{ strain rate gap at test time } \\
\hline start & 0 & $/ /$ & // \\
\hline creep $->1 \mathrm{~Hz}$ & 200 & $19 \%$ & $36 \%$ \\
\hline $1 \mathrm{~Hz}->5 \mathrm{~Hz}$ & 400 & $-15 \%$ & $-13 \%$ \\
\hline $5 \mathrm{~Hz}->10 \mathrm{~Hz}$ & 600 & $-9 \%$ & $-6 \%$ \\
\hline $10->1 \mathrm{~Hz}$ & 800 & $13 \%$ & $28 \%$ \\
\hline $1 \mathrm{~Hz}->$ creep & 1000 & $-41 \%$ & $-43 \%$ \\
\hline creep -> 1Hz & 1500 & $36 \%$ & $53 \%$ \\
\hline $1 \mathrm{~Hz}->5 \mathrm{~Hz}$ & 2000 & $-28 \%$ & $-25 \%$ \\
\hline $5 \mathrm{~Hz}->10 \mathrm{~Hz}$ & 2500 & $-13 \%$ & $-12 \%$ \\
\hline $10->1 \mathrm{~Hz}$ & 3000 & $26 \%$ & $28 \%$ \\
\hline $1 \mathrm{~Hz}->$ creep & 3500 & $-52 \%$ & $-41 \%$ \\
\hline creep -> $1 \mathrm{~Hz}$ & 4500 & $51 \%$ & $45 \%$ \\
\hline $1 \mathrm{~Hz}->5 \mathrm{~Hz}$ & 5500 & $-32 \%$ & $-31 \%$ \\
\hline $5 \mathrm{~Hz}->10 \mathrm{~Hz}$ & 6500 & $-11 \%$ & $-15 \%$ \\
\hline $10->1 \mathrm{~Hz}$ & 7500 & $41 \%$ & $41 \%$ \\
\hline $1 \mathrm{~Hz}->$ creep & 8500 & $-81 \%$ & $-70 \%$ \\
\hline creep -> $1 \mathrm{~Hz}$ & 9500 & $59 \%$ & $59 \%$ \\
\hline $1 \mathrm{~Hz}->5 \mathrm{~Hz}$ & 10500 & $-64 \%$ & $-64 \%$ \\
\hline $5 \mathrm{~Hz}->10 \mathrm{~Hz}$ & 11500 & $-10 \%$ & $-10 \%$ \\
\hline stop & 12500 & // & // \\
\hline
\end{tabular}

Table 9. Summary of the test conditions and results for test T2-2 and T2-3

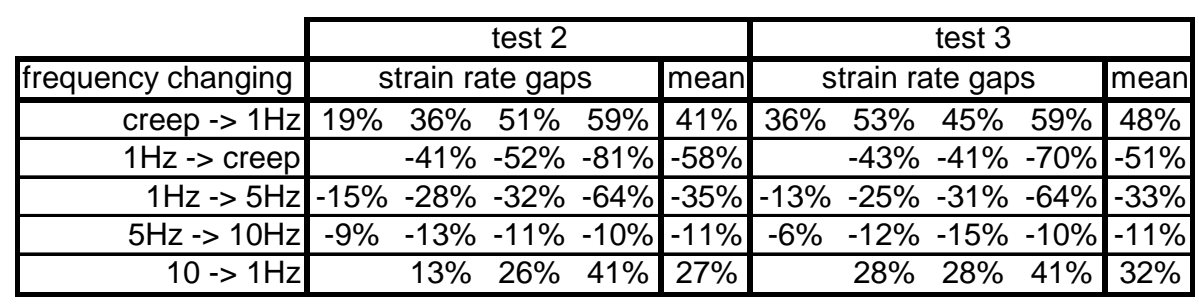

\subsubsection{Influence of frequency on viscoelastic properties}

Mean values of complex modulus, Poisson ratio, and phase angles were calculated for each confining pressure and each testing phase. Results of test T2-2 are 
BLANC, Juliette, GABET, Thomas, HORNYCH, Pierre, PIAU, Jean Michel, DI BENEDETTO, Hervé, 2015, Cyclic triaxial tests on bituminous mixtures , Road materials and pavement design, 1, 16, TAYLOR AND FRANCIS, pp.46-69, DOI: $10.1080 / 14680629.2014 .964293$

presented in table 10. There is no result for the test at $5 \mathrm{~Hz}$, phase 2 and at 1 and $10 \mathrm{~Hz}$, phase 4, because data recording did not work.

Results of test T2-3 are not presented here because evolutions are the same as for test T2-2.

The complex modulus is measured in laboratory using a two point bending test on a parallelepiped. The values at $20^{\circ} \mathrm{C}$ are :

- $\quad 6630 \mathrm{MPa}$ at $1 \mathrm{~Hz}$

- $8040 \mathrm{MPa}$ at $5 \mathrm{~Hz}$

- $11200 \mathrm{MPa}$ at $10 \mathrm{~Hz}$

These values are close to those measured during cyclic sinusoidal tests (T2-2 and T2-3).

Table 10. Values of complex modulus, Poisson ratio and phase angle, from triaxial tests, as function of frequency, for test T2-2

\begin{tabular}{|c|c|c|c|c|c|}
\hline Phase & $\sigma_{\text {rad }}$ & $\left|\mathbf{E}^{*}\right|$ & $\varphi$ & $\left|v^{*}\right|$ & $\varphi_{v}$ \\
\hline $\begin{array}{c}1 \\
\sigma_{\mathrm{r}}=0 \mathrm{kPa}\end{array}$ & $\begin{array}{c}\text { creep } \\
1 \mathrm{~Hz} \\
5 \mathrm{~Hz} \\
10 \mathrm{~Hz} \\
1 \mathrm{~Hz}\end{array}$ & $\begin{array}{c}- \\
6140 \mathrm{MPa} \\
9840 \mathrm{MPa} \\
11600 \mathrm{MPa} \\
7140\end{array}$ & $\begin{array}{c}- \\
30^{\circ} \\
23^{\circ} \\
22^{\circ} \\
29^{\circ}\end{array}$ & $\begin{array}{c}- \\
0.37 \\
0.35 \\
0.34 \\
0.38\end{array}$ & $\begin{array}{l}- \\
-3^{\circ} \\
-4^{\circ} \\
-5^{\circ} \\
-4^{\circ}\end{array}$ \\
\hline $\begin{aligned} & 2 \\
\sigma_{\mathrm{r}}= & 0 \mathrm{kPa}\end{aligned}$ & $\begin{array}{c}\text { creep } \\
1 \mathrm{~Hz} \\
5 \mathrm{~Hz} \\
10 \mathrm{~Hz} \\
1 \mathrm{~Hz}\end{array}$ & $\begin{array}{c}- \\
6100 \mathrm{MPa} \\
- \\
11640 \mathrm{MPa} \\
6070 \mathrm{MPa}\end{array}$ & $\begin{array}{c}- \\
29^{\circ} \\
- \\
21^{\circ} \\
29^{\circ}\end{array}$ & $\begin{array}{c}- \\
0.38 \\
- \\
0.34 \\
0.39\end{array}$ & $\begin{array}{c}- \\
-3.8^{\circ} \\
- \\
-5.1^{\circ} \\
-4.3^{\circ}\end{array}$ \\
\hline $\begin{aligned} & 3 \\
\sigma_{\mathrm{r}}= & 0 \mathrm{kPa}\end{aligned}$ & $\begin{array}{c}\text { creep } \\
1 \mathrm{~Hz} \\
5 \mathrm{~Hz} \\
10 \mathrm{~Hz} \\
1 \mathrm{~Hz} \\
\end{array}$ & $\begin{array}{c}- \\
6100 \mathrm{MPa} \\
9900 \mathrm{MPa} \\
11720 \mathrm{MPa} \\
6030 \mathrm{MPa} \\
\end{array}$ & $\begin{array}{c}- \\
29^{\circ} \\
23^{\circ} \\
21^{\circ} \\
29^{\circ} \\
\end{array}$ & $\begin{array}{c}- \\
0.31 \\
0.31 \\
0.31 \\
0.31 \\
\end{array}$ & $\begin{array}{l}- \\
-2.2^{\circ} \\
-2.3^{\circ} \\
-2.3^{\circ} \\
-2.2^{\circ} \\
\end{array}$ \\
\hline $\begin{array}{c}4 \\
\sigma_{\mathrm{r}}=100 \mathrm{kPa}\end{array}$ & $\begin{array}{c}\text { creep } \\
1 \mathrm{~Hz} \\
5 \mathrm{~Hz} \\
10 \mathrm{~Hz} \\
1 \mathrm{~Hz}\end{array}$ & $\begin{array}{c}- \\
6050 \mathrm{MPa} \\
9910 \mathrm{MPa} \\
- \\
-\end{array}$ & $\begin{array}{c}- \\
29^{\circ} \\
24^{\circ} \\
-\end{array}$ & $\begin{array}{c}- \\
0.4 \\
0.37 \\
-\end{array}$ & $\begin{array}{c}- \\
-4^{\circ} \\
-4.9^{\circ} \\
-\end{array}$ \\
\hline
\end{tabular}

Table 10 shows that:

- $\quad$ For each frequency (1, 5 and $10 \mathrm{~Hz}$ ), complex modulus, Poisson ratio, and phase angle are the same with or without confining pressure.

- With or without confining pressure, the complex modulus increases and the phase angle of the complex modulus decreases when frequency increases. 
- For the Poisson ratio, the conclusions are less clear, due to some experimental scatter, but it seems that increasing the frequency leads to a decrease of the Poisson ratio and an increase of the phase angle of this coefficient. However, this phase angle remains small (between $2^{\circ}$ and $5^{\circ}$ ).

Di Benedetto et al. (2008) carried out similar studies, without confining pressure, and have come to the same conclusions. It seems that variations of viscoelastic properties with frequency are not affected by the confining pressure, for the range of pressures applied in this study $(0 \mathrm{kPa}$ to $200 \mathrm{kPa})$, which is representative of pavement loading conditions.

\section{Conclusions and future developments}

\subsection{Conclusions}

In this paper cyclic triaxial thermo-regulated tests on bituminous mixtures are presented. These tests were performed at different loading frequencies and confining pressures, to evaluate the influence of these parameters on the viscoelastic properties and permanent deformations of the material.

Two types of test procedures were developed and applied to our specimens. The test procedure T1 was a classical cyclic triaxial test, which consisted in applying a single loading level and frequency all along each test. However, some problems of repeatability where emphasized. They were attributed to the manufacturing process and to scatter of specimen densities and structures. The second procedure named T2 was developed to overcome problems of repeatability. This procedure consisted in applying successively different loading conditions (confining pressure or loading frequency) on a single specimen, to avoid sample preparation effects. On these tests, a focus was made on the strain rate variations.

Our experimental program highlighted several interesting results. Firstly, it showed that slight variations of specimen density and structure due to the manufacturing process can have a significant effect on permanent strain behaviour. Once overtaken these problems of repeatability, tests have clearly shown that :

- Increasing the confinement reduces significantly permanent deformations.

- Increasing the loading frequency reduces permanent deformation rate

- $\quad$ Creep tests lead to less deformation than sinusoidal cyclic tests at low frequency, at the same mean value. This emphasises the influence of cyclic solicitations on the response of bituminous mixtures.

- In terms of viscoelastic properties, results have confirmed the influence of the frequency of loading on the viscoelastic response of the material, classically observed in complex modulus tests. The tests have also shown no significant effect of the confining pressure on the axial response of the material.

It is clear that both the triaxial aspect of loading, and cyclic effects cannot be neglected when studying bituminous mixtures. From a rheological point of view, 
BLANC, Juliette, GABET, Thomas, HORNYCH, Pierre, PIAU, Jean Michel, DI BENEDETTO, Hervé, 2015, Cyclic triaxial tests on bituminous mixtures, Road materials and pavement design, 1, 16, TAYLOR AND FRANCIS, pp.46-69, DOI: $10.1080 / 14680629.2014 .964293$

this highlights that their behaviour results from the contributions of the viscous binder (viscoelastic properties changing with temperature and frequency) and of the granular skeleton (influenced by the triaxial loading path). From these observations, it can be concluded that a good rheological model for a bituminous mixture needs to take into account all these characteristics : viscoelasticity, viscoplasticity, thermosuceptibility, cycling effects..

\subsection{Outlook}

The final objective of the presented study is to develop efficient rheological models for FEM simulations for the prediction of the permanent deformations of pavement structures, under monotonic and cyclic loading. Expected applications are for instance :

- $\quad$ Rutting of road pavements under severe loading conditions (channelized traffic, slopes, etc..)

- Evaluation of the effects of high temperatures on pavement rutting (impacts of climate change)

- $\quad$ Rutting of industrial platforms under static or moving loads

- $\quad$ Effect of very high loads or tyre pressures on pavements (aircraft loads...). 


\section{Bibliography}

Airey G., Rahimzahed B., Collop A., "Viscoelastic linear limits for bituminous materials”, Materials and Structures, Vol 36, pp 643-647, 2003

Airey G., Rahimzahed B., Collop A., "Linear rheological behavior of bituminous paving materials”, Journal of materials in civil engineering, Vol 16, pp 212-220, 2004

Brown S., "Essais triaxiaux sur enrobés bitumineux et chargement répété ou en fluage”, Bulletin de liaison du laboratoire des ponts et chaussées, n5, pp 125138, 1977

Brown S., Snaith M., "The measurement of recoverable and irrecoverable deformations in the repeated load triaxial test”, Geotechnique, n²4, pp 255-259, 1974

Chabot A., Chupin O., Deloffre L., Duhamel D., "Viscoroute 2.0: a tool for the simulation of moving load effects on asphalt pavement”, International Journal Road Materials and Pavement Design Special Issue on Recent Advances in Numerical Simulation of Pavements, Vol 11 (2), pp 227-250, 2010, DOI:10.3166/RMPD.11.227-250

Chailleux E., Such C., Ramond G., de La Roche C., “A mathematical-based mastercurve construction method applied to complex modulus of bituminous materials”, International Journal Road Materials and Pavement Design, Vol 7, Special Issue EATA, pp 75-92, 2006

Chupin O., Chabot A., Piau J.-M., Duhamel D., "Influence of sliding interfaces on the response of a visco-elastic multilayered medium under a moving load”, International Journal of Solids and Structures, Vol 47, pp 3435-3446, 2010, DOI:10.1016/j.ijsolstr.2010.08.020

Clec'h P., Sauzeat C. and Di Benedetto H., "Multidirectional behaviour of bituminous mixtures”, Proceedings of Bearing Capacity of Roads, Railways and Airfields, pp 377-386, Champaign, Illinois, USA, 2009

De Visscher J., Maeck J., Vanelstraete A., “The permanent deformation law of asphalt mixtures: investigation of the effect of mix composition and material properties”, Proceedings of $10^{\text {th }}$ International Conference on Structural Design of Asphalt Pavements, Quebec, Canada, August 2006

Di Benedetto, H., Nguyen, H. M., Pouget, S., Sauzéat, C., “Time-temperature superposition principle for bituminous mixtures: three dimensional approach and extension in the non linear domain”, ICTI, Beijing, China, 2008

Di Benedetto, H., Sauzéat, Bilodeau K., Buannic M., Mangiafico S., Nguyen Q.T., Pouget, S., Tapsoba N., Van Rompu J., "General overview of the timetemperature superposition principle for materials containing bituminous binder”, 
BLANC, Juliette, GABET, Thomas, HORNYCH, Pierre, PIAU, Jean Michel, DI BENEDETTO, Hervé, 2015, Cyclic triaxial tests on bituminous mixtures, Road materials and pavement design, 1, 16, TAYLOR AND FRANCIS, pp.46-69, DOI: $10.1080 / 14680629.2014 .964293$

International Journal of Roads and Airports, Vol 1 (1), pp 35-52, 2011, DOI:10.5568/ijra.2011-01-03.3552

Di Benedetto, H., Sauzéat, C., Sohm, J., "Stiffness of bituminous mixtures using ultrasonic wave propagation”, International Journal Road Materials and Pavement Design, Vol 10, pp789-814, 2009

Dongmo B., Caractérisation des déformations d’orniérage des chaussées, $\mathrm{PhD}$ Thesis ENTPE-INSA, 2005 [In French] (http://theses.insalyon.fr/publication/2005ISAL0020/these.pdf)

Ebels L., Jenkins K., "Determination of materials properties of bitumen stabilised materials using tri-axial testing”, Proceedings of $10^{\text {th }}$ International Conference on Structural Design of Asphalt Pavements, Quebec, Canada, August 2006

EN 12697-7, European standard, Test methods for hot mix asphalt - part 7 : Determination of bulk density of bituminous specimens by gamma rays, June 2003

EN 12697-22, European standard, Test methods for hot mix asphalt - part 22 : Wheel tracking, September 2007

EN 12697-26, European standard, Test methods for hot mix asphalt - part 26 : Stiffness, December 2004

EN 12697-33+A1, European standard, Test methods for hot mix asphalt - part 33 : Specimen prepared by roller compactor, September 2007

Gabet T., Comportement triaxial du béton sous fortes contraintes : influence du trajet de chargement, PhD Thesis, Université Joseph Fourier, 2006 [In French] (http://tel.archives-ouvertes.fr/docs/00/11/88/82/PDF/thesegabet_30_11_06.pdf)

Gabet T., Di Benedetto H., Perraton D., De Visscher J., Gallet T., Bankowski W., Olard F., Grenfell J., Bodin D., Sauzéat C., (RILEM TC 206-ATB, TG3 : Mechanical testing of mixtures), "French wheel tracking round robin test on a polymer modified bitumen mixture”, Materials and Structures, Vol 44, pp 10311046, 2011

Heck J.V., Modélisation des déformations réversibles et permanentes des enrobés bitumineux : application à l’orniérage des chaussées, $\mathrm{PhD}$ Thesis, Université de Nantes, 2001 [In French]

Kappl K., Blab R., "Enhanced algorithms for the derivation of material parameters from triaxial cyclic compression tests on asphalt specimen”, in $7^{\text {th }}$ RILEM Symposium advanced testing characterization of bituminous materials, pp 357 366, Rhodes, Greece, 2009

Neifar M., Comportement thermomécanique des enrobés bitumineux : expérimentation et modélisation, PhD Thesis, ENTPE-INSA, 1997 [In French] 
Nguyen H. M., Pouget S., Di Benedetto H., Sauzéat C., "Time-Temperature Superposition Principle for bituminous mixtures”, European Journal of Environmental and Civil Engineering, [doi:10.3166/ejece.13.1095-1107], pp. 1095-1107, 2009

Perraton D., Di Benedetto H., Sauzéat C., De La Roche C., Bankowski W., Partl M., Grenfell J., "Rutting of bituminous mixtures : wheel tracking tests campaign analysis”, Materials and Structures, Vol 44(5), pp 969-986, 2011

Sohm J., Prédiction des déformations permanentes des matériaux bitumineux, $\mathrm{PhD}$ Thesis, LCPC, 2011 [In French] , (http://tel.archivesouvertes.fr/docs/00/77/75/61/PDF/these_SOHM_VF.pdf)

Sohm J., Gabet T., Hornych P., Piau J.M., Di Benedetto H., "Creep tests on bituminous mixtures and modelling", International Journal Road Material and Pavement Design, Vol 13 (4), pp 832-849, 2012, DOI:10.1080/14680629.2012.735795

Sohm J., Hornych P., Gabet T., Di Benedetto H., "Cyclic triaxial apparatus for the study of permanent deformations of bituminous mixtures", Proceedings of $12^{\text {th }}$ International Conference on Structural Design of Asphalt Pavements, Nagoya, Japan, August 2010

Taherkhani H., Collop A., "Compressive uniaxial and triaxial testing of asphaltic mixtures", Proceedings of $10^{\text {th }}$ International Conference on Structural Design of Asphalt Pavements, Quebec, Canada, August 2006

Taherkhani, H., Grenfell, J., Collop, A., Airey, G., Scarpas, A., “Characterization of repeated creep recovery behaviour of asphaltic mixtures", Advanced characterisation of pavement and soil engineering materials, Athens, Greece, 2007

Verstraeten, J., "Bituminous material with a high resistance to flow rutting", Proceedings of PIARC, technical committee on Flexible Roads, Belgium, 1995 